1

3

\title{
Mineralogy and diagenesis of Mars-analog paleosols from eastern Oregon, USA
}

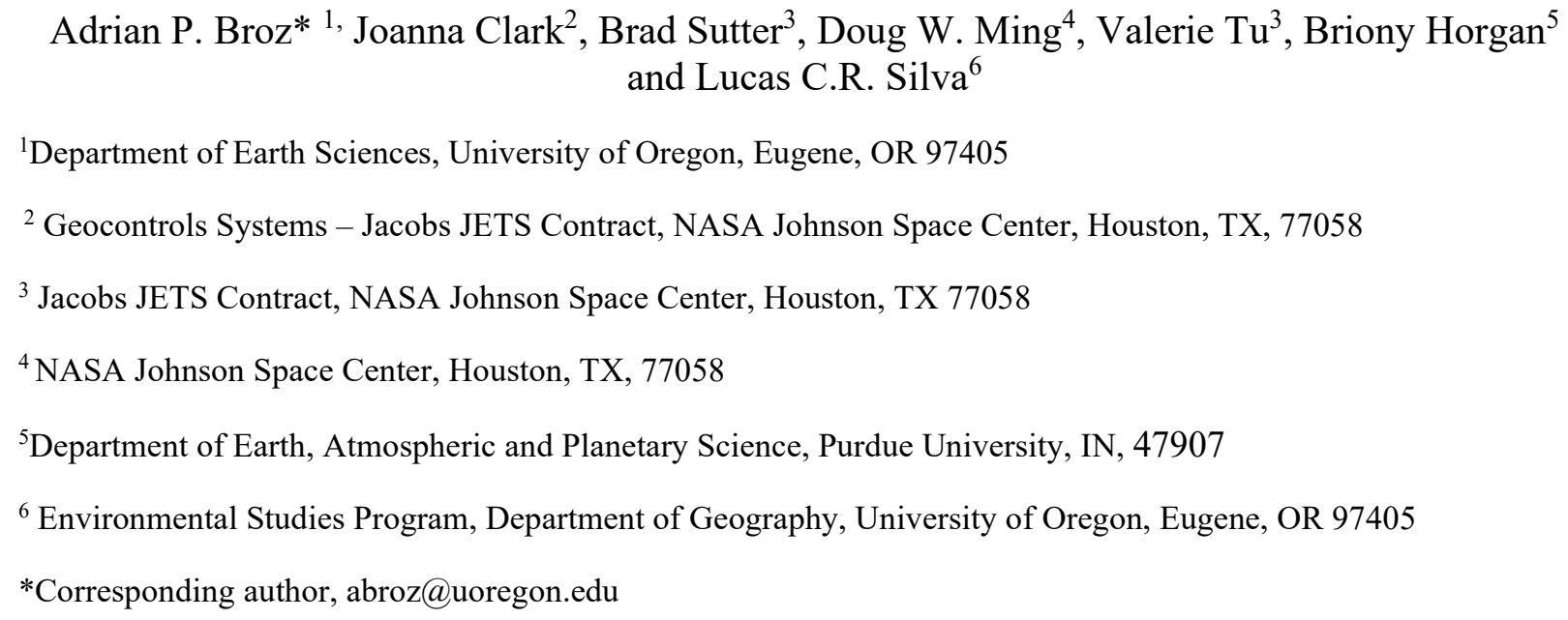




\title{
Mineralogy and diagenesis of Mars-analog paleosols from eastern Oregon, USA
}

\author{
Adrian P. Broz* 1, Joanna Clark², Brad Sutter ${ }^{3}$, Doug W. Ming ${ }^{4}$, Valerie Tu ${ }^{3}$, Briony Horgan ${ }^{5}$ \\ and Lucas C.R. Silva ${ }^{6}$ \\ ${ }^{1}$ Department of Earth Sciences, University of Oregon, Eugene, OR 97405 \\ ${ }^{2}$ Geocontrols Systems - Jacobs JETS Contract, NASA Johnson Space Center, Houston, TX, 77058 \\ ${ }^{3}$ Jacobs JETS Contract, NASA Johnson Space Center, Houston, TX 77058 \\ ${ }^{4}$ NASA Johnson Space Center, Houston, TX, 77058 \\ ${ }^{5}$ Department of Earth, Atmospheric and Planetary Science, Purdue University, IN, 47907 \\ ${ }^{6}$ Environmental Studies Program, Department of Geography, University of Oregon, Eugene, OR 97405 \\ *Corresponding author, abroz@uoregon.edu
}

Ancient (4.1-3.7-billion-year-old) layered sedimentary rocks on Mars are rich in clay minerals which formed from aqueous alteration of the Martian surface. Many of these sedimentary rocks appear to be composed of vertical sequences of $\mathrm{Fe} / \mathrm{Mg}$ clay minerals overlain by Al clay minerals that resemble paleosols (ancient, buried soils) from Earth. The types and properties of minerals in paleosols can be used to constrain the environmental conditions during formation to better understand weathering and diagenesis on Mars. This work examines the mineralogy and diagenetic alteration of volcaniclastic paleosols from the Eocene-Oligocene (43-28 Ma) Clarno and John Day Formations in eastern Oregon as a Mars-analog site. Here, paleosols rich in Al phyllosilicates and amorphous colloids overlie paleosols with $\mathrm{Fe} / \mathrm{Mg}$ smectites that altogether span a sequence of $\sim 500$ individual profiles across hundreds of meters of vertical stratigraphy. Samples collected from three of these paleosol profiles were analyzed with visible/near-infrared (VNIR) spectroscopy, X-ray diffraction (XRD), and evolved gas analysis (EGA) configured to operate like the SAM-EGA instrument onboard Curiosity Mars Rover. Strongly crystalline Al/Fe dioctahedral phyllosilicates (montmorillonite and nontronite) were the major phases identified in all samples with all methods. Minor phases included the zeolite mineral clinoptilolite, as well as andesine, cristobalite, opal-CT and gypsum. Evolved $\mathrm{H}_{2} \mathrm{O}$ was detected in all samples and was consistent with adsorbed water and the dehydroxylation of a dioctahedral phyllosilicate, and differences in $\mathrm{H}_{2} \mathrm{O}$ evolutions between montmorillonite and nontronite were readily observable. Detections of hematite and zeolites suggested paleosols were affected by burial reddening and zeolitization, but absence of illite and chlorite suggest that potash metasomatism and other, more severe diagenetic alterations had not occurred. The high clay mineral content of the observed paleosols (up to $95 \mathrm{wt}$ \%) may have minimized diagenetic alteration over geological time scales. Martian paleosols rich in $\mathrm{Al}$ and Fe smectites may have also resisted severe diagenetic alteration, which is favorable for future in-situ examination. Results from this work can help distinguish paleosols and weathering profiles from other types of sedimentary rocks in the geological record of Mars. 


\section{This paper is a non-peer reviewed preprint submitted to EarthArXiv}

\section{Introduction}

Today the surface of Mars is frigid, wind-deflated and barren, but there is extensive geological evidence for transient warm and wet habitable surface conditions in the Noachian (4.1-3.7 Ga) period of early Mars ${ }^{1-4}$. Orbital sensing of the Martian surface has revealed clay mineral deposits in thousands of locations, wherever Noachian-age terrains are not obscured by dust, sand, or overlying strata ${ }^{5-8}$. These ancient deposits are rich in smectite clay minerals and other hydrated phases, suggesting formation in subsurface and surface environments from the weathering of mafic rocks and sediments with liquid water.

While some phyllosilicates on Mars are associated with lacustrine deposition in surface environments (e.g., ${ }^{9}$ ) many phyllosilicate detections occur in regionally widespread deposits, inconsistent with deposition in basin settings. Two hypotheses to explain the formation, occurrence and distribution of these regionally widespread phyllosilicates on Mars are: 1) subsurface hydrothermal activity, diagenesis and/or authigenesis ${ }^{10-14}$ and, 2) surface pedogenic alteration (e.g., subaerial chemical weathering) ${ }^{2,6,14,15}$. In some locations, trioctahedral smectites exhibiting lateral variations in $\mathrm{Al}$ and $\mathrm{Fe} / \mathrm{Mg}$ smectites intermixed with chlorite, serpentinite, talc and zeolite are consistent with formation in hydrothermal subsurface environments, diagenesis, and/ or authigenesis during sediment emplacement ${ }^{13,16,17}$. However, dioctahedral smectites often outcrop as extensive vertical profiles of Fe/Mg smectites overlain by $\mathrm{Al}$ smectites, suggesting subaerial formation in surface environments, consistent with pedogenesis (soil formation) or large-scale leaching of sediments ${ }^{14}$.

Paleosols are ancient, buried soils that are lithified into sedimentary rocks. On Earth, paleosols are a geological record of the atmospheric composition, climate, topography and organisms present before soil burial ${ }^{18}$. Paleosols are created by removal from their soil-forming factors, sometimes because of change in those factors, but most often by rapid burial. The deposition of volcanic ash, flood basalts, sedimentation from flooding, landslides, and tsunamites all rapidly bury surface environments. Sequences of paleosols form when soils are periodically buried, for example by repeated volcanic eruptions which emplace tephra or lava onto soil surfaces, followed by successive pedogenic weathering of emplaced tephra or lava, and then subsequent burial by another eruption. Flooding by rivers also buries paleosols within alluvial sequences, and dune migration buries paleosols within eolian sequences. On Earth, sequences of paleosols formed by periodic burial can record weathering, paleoclimate and diagenetic alteration over $10^{7}$ year timescales ${ }^{19,20}$.

Paleosols can be useful tools for interpreting ancient climates of Earth and Mars ${ }^{21-23}$. The types and properties of minerals in Mars-analog paleosols can be used to help understand the nature of weathering and diagenesis on Mars ${ }^{24,25}$ but they remain relatively understudied as Mars-analog sites. The objective of this study was to examine the mineralogy and diagenetic alterations of Mars-analog paleosols from eastern Oregon, USA using analytical techniques similar to those onboard current and future missions to Mars.

\subsection{Paleosols at John Day Fossil Beds National Monument}

The John Day Fossil Beds National Monument in eastern Oregon, USA, is an established Marsanalog site known for similarities in mineralogy and stratigraphy to clay-bearing sedimentary rocks on Mars ${ }^{20,26,27}$. Here, Eocene and Oligocene (42-28 Ma) sedimentary rocks are a well-preserved sequence of andesitic to rhyodacitic paleosols ${ }^{15,28-30}$. The $\sim 400$-meter-thick sequence is host to over 500 individual clay mineral-rich (30-95 wt. \%) paleosols spanning 15 Myr through the climatic cooling of the EoceneOligocene boundary (Figure 1). A record of dramatic climate change is preserved in the mineralogy of paleosols from the Eocene/Oligocene-age Clarno and John Day Formations, transitioning from high kaolinite and oxide abundances at the bottom (warm and wet Eocene), to high smectite abundances (drying out late Eocene), and then poorly crystalline phases at the stratigraphic top of the section (cool and dry Oligocene) ${ }^{28,29}$. 


\section{This paper is a non-peer reviewed preprint submitted to EarthArXiv}

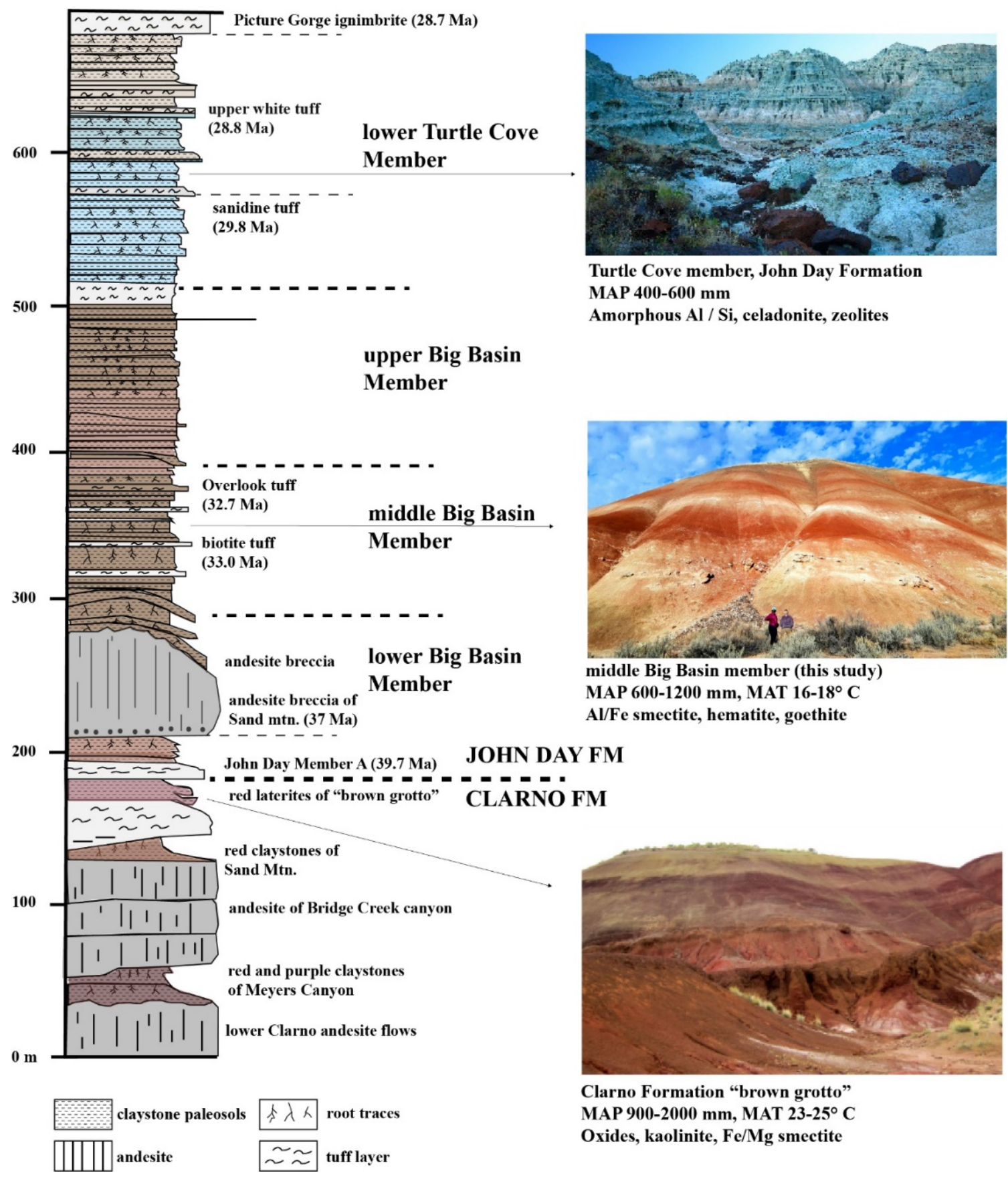

Figure 1. A sequence of Eocene through Oligocene (43-28 Ma) volcaniclastic paleosols in the Clarno and John Day Formations, John Day Fossil Beds National Monument (redrawn from ${ }^{28}$. Mean annual precipitation (MAP) and mean annual temperature (MAT) estimates are from Retallack et al (2000) ${ }^{31}$.

Stratigraphically lowest in the section are deeply weathered red and purple lateritic paleosols 110 (Oxisols and Ultisols in US Taxonomy ${ }^{32}$ ) within the uppermost Clarno and lowermost John Day 111 Formations in the Painted Hills ( 42 Ma). These paleosols formed under a warm and wet climate of an 112 estimated 900-2000 mm mean annual precipitation (MAP) and mean annual temperature (MAT) of 23$11325^{\circ} \mathrm{C}^{29}$ (Figure 2). This unit of the section generally resembles the basal Fe/ $\mathrm{Mg}$ clay unit at Mawrth 114 Vallis ${ }^{20}$. The Clarno paleosols have accumulations of oxides, kaolinite and Fe/Mg smectites and are 


\section{This paper is a non-peer reviewed preprint submitted to EarthArXiv}

115 erosionally truncated and abruptly overlain by less deeply weathered $\mathrm{Al} / \mathrm{Fe}$ smectite-rich paleosols

116 (Inceptisols and Alfisols) of the middle Big Basin Member of the John Day Formation ( 33 Ma, samples 117 from this location examined in this study). This truncation surface is correlated with the international 118 Eocene-Oligocene boundary ${ }^{29}$. Big Basin member soils appear to have formed under a markedly cooler

119 (MAT 16-18 ${ }^{\circ}$ ) and drier (MAP 600-1200 mm) climate relative to the early Eocene ${ }^{31}$. Stratigraphically 120 above, in the Turtle Cove paleosols, another erosional truncation marks the base of the late Oligocene 121 ( 28 Ma) lower Turtle Cove Member of the John Day Formation which has minimally weathered 122 calcareous paleosols (Aridisols and Andisols) containing abundant celadonite, calcite and amorphous 123 colloids (imogolite, ferrihydrite and allophane) which indicate an even drier (MAP 400-600 mm) climate 124 during the late Oligocene ${ }^{33}$. 


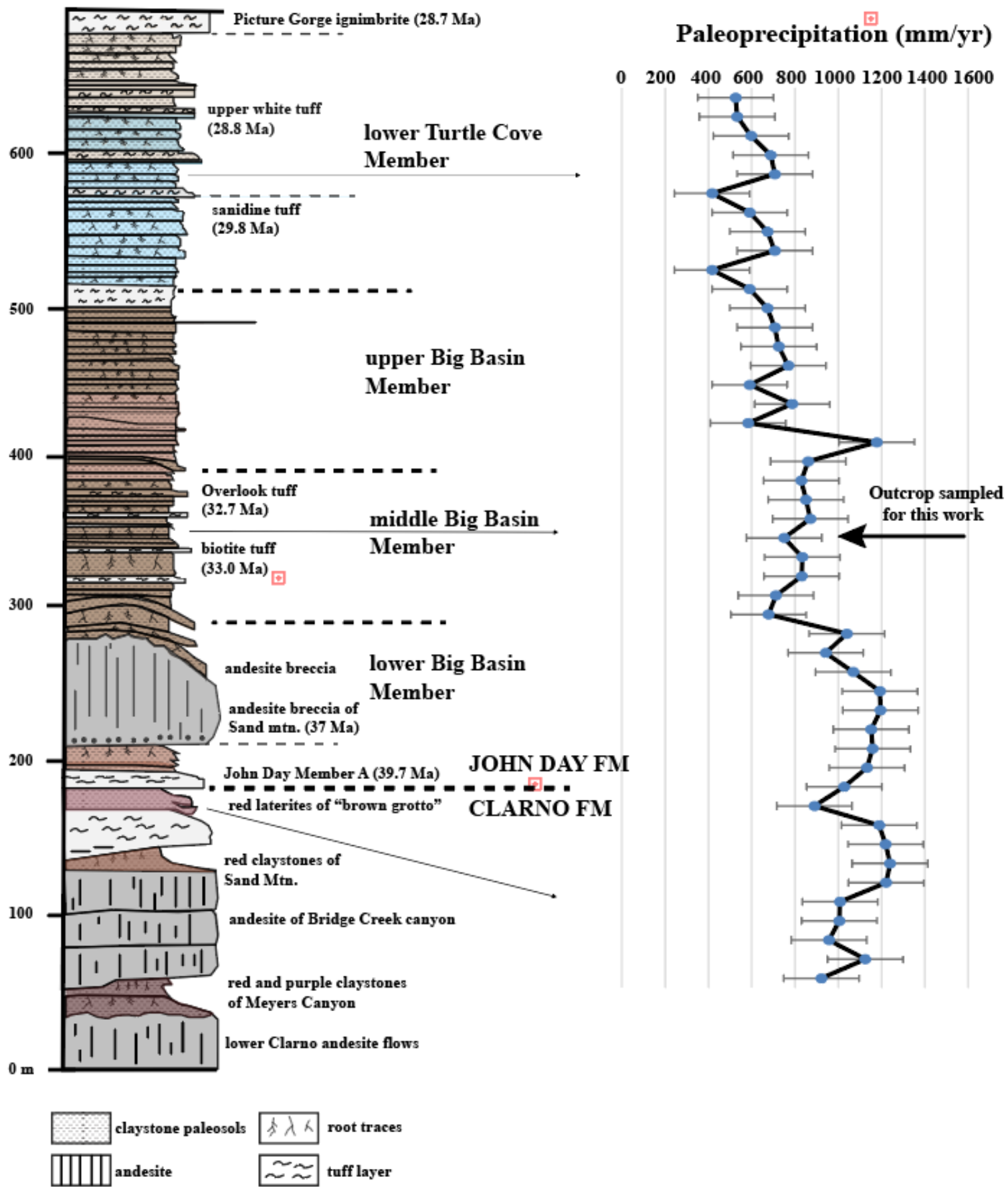

Figure 2. Declining precipitation through the Eocene/Oligocene boundary inferred from the mineralogy of paleosols from the Clarno and John Day Formations (after Bestland et al. (1997) and Sheldon et al (2002). The stratigraphic level of paleosols analyzed in this work is indicated (black arrow). Paleoprecipitation estimates are from Sheldon et al (2002) are from an equation relating molecular weathering ratios (Bases/alumina $[\mathrm{CaO}+\mathrm{MgO}+$ $\left.\mathrm{Na}_{2} \mathrm{O}+\mathrm{K}_{2} \mathrm{O} / \mathrm{Al}_{2} \mathrm{O}_{3}\right]$ to mean annual precipitation from a database of modern U.S soils $(\mathrm{r}=0.79$, standard error $=$

$132179 \mathrm{~mm})^{31}$. 


\section{This paper is a non-peer reviewed preprint submitted to EarthArXiv}

The Turtle Cove Member (late Oligocene) is composed of light brown and green colored Andisol (volcanic soils) and Aridisol (desert soils) paleosols that overlie the upper Big Basin member of the John Day Formation. The Turtle Cove Member has increased amounts of amorphous phases and calcite as well as the blue to green-colored clay mineral celadonite. Celadonite in the Turtle Cove paleosols is thought to form from the recrystallization of poorly crystalline smectite and/ or amorphous phases ${ }^{29}$. Although spectral signatures of celadonite and/or glauconite have been noted in the Mawrth Vallis region ${ }^{34}$, it is currently unclear if celadonite is a component of putative Martian paleosols. In any case, the Turtle Cove paleosols have a dramatic reduction in smectite abundance and near absence of kaolin-group clays relative to the Clarno Formation paleosols at the base of the section ${ }^{15,29}$. Similarly, the accumulation of amorphous / nanocrystalline phases is observed at the stratigraphic top of the Noachian-age section at Mawrth Vallis ${ }^{35}$ which is consistent with a drier, colder climate that was not sufficient to weather volcanic ash into more crystalline phases.

Stratigraphically above the Turtle Cove Member paleosols, approximately 300 vertical meters of flood basalts from the Columbia River Group cap the entire sequence. Based on these mineralogical transitions, the Eocene-age paleosols at the base of the section have accumulations of kaolinite and oxides that reflect a subtropical and humid climate, late Eocene/ early Oligocene paleosols in the middle of the section have $\mathrm{Al} / \mathrm{Fe}$ smectites associated with a more arid climate, and paleosols with accumulations of nanophase aluminosilicates and amorphous phases higher in the stratigraphy indicate stepwise and cooling and drying during the late Oligocene ${ }^{29}$. Sequences of paleosols within the John Day Formation are similar in mineralogy and stratigraphy to dioctahedral clay mineral sequences at Mawrth Vallis ${ }^{15,26}$ and record a stepwise cooling and drying similar to proposed climates of early Mars.

\subsection{Comparisons to putative Martian paleosols}

Remote sensing of the Martian surface has revealed Noachian-age (4.1-3.7 Ga) layered sedimentary rocks rich in dioctahedral clay minerals that appear to be distributed globally across the surface of Mars $6,7,14$. These rocks are generally characterized by strong spectral signatures of $\mathrm{Al}$ clays overlying $\mathrm{Fe} / \mathrm{Mg}$ clays over hundreds of vertical meters of stratigraphy. One hypothesis for their formation is from pedogenic weathering of mafic sediments such as volcanic ash during intermittent warm periods early in Mars' history $6,14,24,36$. These altered sediments are detected mantling topographic highs including the summits and flanks of volcanoes, consistent with formation in surface environments via pedogenic weathering ${ }^{4}$. Many of the clearest examples of putative Martian paleosols are observed in crater rims ${ }^{15,26}$.

The rim of Muara Crater at Mawrth Vallis is host to a $150-200 \mathrm{~m}$ thick Fe/Mg smectite unit (topped by sulfate deposits in some areas) overlain by a $50 \mathrm{~m}$ thick Al-phyllosilicate or opal unit which transitions upward into poorly crystalline aluminosilicates or nanophase materials ${ }^{37,38}$. The entire section is then capped by an igneous deposit which appears to be composed of lava and/or basaltic sand ${ }^{14}$, similar to the stratigraphy of the John Day Formation paleosols which are capped by approximately 300 meters of flood basalts. The layering of dioctahedral $\mathrm{Al}$ clay minerals and $\mathrm{Fe} / \mathrm{Mg}$ clay minerals over hundreds of vertical meters suggests a subaerial formation environment for the clay minerals ${ }^{14,24}$, and therefore congruent pedogenic alteration of basaltic parent material under warm and wet conditions is one hypothesis to explain the exceptional thickness of the Mawrth Vallis sequence $6,15,39,40$.

The compositional stratigraphy at Mawrth Vallis has been proposed to be either a paleosol sequence ${ }^{15}$ or a deep weathering profile (e.g., saprolite mantle) ${ }^{24}$. Terrestrial paleosol sequences are stacks of individual, meter-scale weathering profiles that form from repeated pedogenic alteration followed by burial. With repeated pedogenic alteration and burial by tephra or lava over $10^{6}-10^{7} \mathrm{yr}$ scales, volcaniclastic sequences of individual paleosol profiles can reach hundreds to thousands of meters in vertical thickness ${ }^{41,42}$. Rapid burial of each paleosol surface via emplacement of tephra or lava can also create favorable conditions for the preservation of biosignatures. In terrestrial settings, each individual profile within the sequence typically accumulates and preserves organic carbon in the near-surface layers, just below the uppermost burial layer ${ }^{43}$, which often presents at field scale as a nonconformity ${ }^{18}$

By contrast, deep weathering profiles are the products of intense, long-term chemical weathering across tectonically stable landscapes and instead are characterized by a single, massive, and uninterrupted 


\section{This paper is a non-peer reviewed preprint submitted to EarthArXiv}

weathering profile. They are most common at terrestrial intertropical latitudes between $35^{\circ} \mathrm{N}$ and $35^{\circ} \mathrm{S}$

${ }^{44}$. The vertical extent of deep weathering profiles, which includes weathered residuum and sediments overlying basement rocks, varies from a few meters to over 150 meters, dependent on climate, tectonic activity, age of the land surface and the properties of the bedrock ${ }^{44,45}$. The generally flat-lying topographic relief of deep weathering profiles allows for leaching of weathering products, usually when the downward progression of the weathering front exceeds the erosion rate ${ }^{45}$. The weathering front typically obliterates any primary sedimentary structures such as relict bedding of the basal unweathered layers in each profile ( $\mathrm{C}$ and $\mathrm{R}$ horizons in US Soil Taxonomy). The organic preservation potential of terrestrial deep weathering profiles (e.g., laterites) is generally considered to be poor, largely in part due to leaching and/or oxidation of endogenous organic molecules derived from surface biomass ${ }^{46}$. However, Noachian (4.1-3.7 Ga) surface weathering may have proceeded under an anoxic atmosphere and was possibly similar in nature to Archean (4.1-2.6 Ga) anoxic pedogenic weathering on Earth. Reducing conditions during ancient pedogenic weathering creates favorable taphonomic conditions for the preservation of biosignatures over geological time scales, including carbonaceous microfossils ${ }^{47}$ and organic carbon associated with mineral surfaces ${ }^{48,49}$. Therefore, distinguishing between paleosol sequences and deep weathering profiles has major implications for paleoclimate interpretations and biosignature preservation throughout the Mawrth Vallis region ${ }^{14}$.

The thickness of the Mawrth Vallis compositional stratigraphy ( 150 -200 m) exceeds the thickness of terrestrial deep weathering profiles (typically less than $100 \mathrm{~m}$ ). The stratigraphy could have resulted from sediment deposition and then extensive vertical leaching by liquid water during post-depositional diagenesis, but such deep leaching profiles on Earth rarely exceed $150 \mathrm{~m}$ in thickness ${ }^{15}$. The exposed stratigraphy at Mawrth Vallis also appears to have lateral and vertical diversity beyond the overall Fe/Mg smectite - Al-Si phase stratigraphy ${ }^{15}$. Lateral and vertical diversity of clay minerals is not found in deep weathering profiles but is common in paleosols, which have diversity in composition and color at $\sim 1$ meter scales. However, the 18 meter/pixel resolution of CRISM ${ }^{5}$ may limit interpretations of the mineralogical diversity of these deposits on Mars because the fine-scale features of paleosols may be obscured at these resolutions. There also appears to be relict bedding of dark-toned sands throughout the deposit, which suggests the coarse-sized fraction of the parent material may be preserved in certain layers as less-weathered bottom layers ( $\mathrm{C}$ and $\mathrm{R}$ horizons) of paleosols. This relict bedding would presumably be destroyed if the entire deposit was a deep weathering profile ${ }^{15}$. Dioctahedral phyllosilicate layers at Mawrth Vallis may be a paleosol sequence that formed under a semi-arid climate, overlain by a thinner leaching profile and capped by a relatively unaltered igneous deposit ${ }^{20,50}$. This stratigraphy is consistent with climate hypotheses for early Mars, including a Noachian hyperarid frigid paleoclimate alternating with warmer and wetter conditions ${ }^{14,25}$. A similar pedogenic-like stratigraphy of dioctahedral Al clays overlying Fe/Mg clays has been detected in hundreds of locations across the surface of Mars which suggests widespread surface weathering was not limited to the Mawrth Vallis region ${ }^{6,7}$. Since many of the layered clay mineral sequences on Mars resemble terrestrial paleosols ${ }^{51}$, a detailed mineralogical analysis of paleosols from Earth can help with identification and interpretation of these deposits.

It is important to note that the results from this study alone cannot determine if the Mawrth Vallis stratigraphy is a paleosol sequence or a deep weathering profile. Rather, this study seeks to determine if pedogenic and diagenetic features in ancient terrestrial samples can be identified with a multi-instrument suite relevant to current and future missions on Mars. This determination is a critical first step to constrain the formation mechanisms of possible pedogenic deposits on Mars.

\subsection{Terrestrial analogs as a window into surface weathering on Mars}

In this study, we examined early Oligocene (33 Ma) paleosol profiles from the Mars-analog paleosol sequence in eastern Oregon (Figure 2). Orbital and in-situ visible-near infrared (VNIR) spectroscopic techniques are used by current and future missions to Mars and are a useful tool for identifying minerals and diagenetic features across the global Martian surface ${ }^{5,52,53}$. Here, in-situ visible-near infrared spectroscopy was performed to identify clay minerals, zeolites and oxides in bulk paleosol samples. The 


\section{This paper is a non-peer reviewed preprint submitted to EarthArXiv}

Curiosity Mars rover employs in-situ X-ray diffraction (XRD) for identification and quantification of crystalline minerals in rocks, sediments and soils on Mars ${ }^{54,55}$. Qualitative X-ray diffraction was used in this study to identify crystalline minerals in bulk paleosol samples from the three consecutive paleosol profiles. Lastly, samples were analyzed with an instrument calibrated to use analytical conditions similar to the Sample Analysis at Mars evolved gas analysis (SAM-EGA) instrument onboard the Curiosity rover ${ }^{56}$. The purpose of this analysis was to constrain the mineralogy of hydrated phases in samples, specifically by examining evolutions of $\mathrm{H}_{2} \mathrm{O}$ and $\mathrm{SO}_{2}$ from bulk paleosol samples during heating. Since thermal techniques such as evolved gas analysis will fly onboard future missions to Mars (e.g. ExoMars 2022 Rosalind Franklin rover ${ }^{57}$ ), a detailed characterization of terrestrial paleosol mineralogy via evolved gas analysis can help constrain the formation mechanism(s) of dioctahedral clay-bearing sedimentary rocks on Mars.

\section{Methods}

\subsection{Sample collection}

The paleosols examined in this study were collected from the Middle Big Basin Member of the John Day Formation (Figure 2) near the Painted Hills Unit of the John Day Fossil Beds National Monument in eastern Oregon, USA. For this work, we reoccupied paleosol profiles first described and sampled by Retallack et al. (2000) ${ }^{29}$. New samples from three individual paleosols in vertical succession were collected approximately $7 \mathrm{~km} \mathrm{SW}$ of the entrance to the Painted Hills unit of the John Day Formation (44.631105, -120.213107), in the Middle Big Basin Member of the John Day Formation, approximately $6 \mathrm{~m}$ above the local Eocene-Oligocene boundary (Figure 2). Samples were chosen from this site because it contained a sequence of three successive paleosols at a general topographic position (e.g., badland toeslope) that may be accessible for in-situ analysis on Mars by future landed missions including rovers and /or astronauts. Furthermore, previous ${ }^{40} \mathrm{Ar} /{ }^{39} \mathrm{Ar}$ dating of volcanic tuffs above and below the sampling location allowed for a constrained age of $33.0+/-0.10$ to $32.7+/-0.03 \mathrm{Ma}$ (Biotite Tuff and Overlook Tuff, respectively) ${ }^{28}$.

Samples were collected by first trenching to $\sim 30 \mathrm{~cm}$ into the outcrop to remove the modern weathering zone and to expose the underlying claystone paleosols. This was followed by sampling with a rock hammer down a vertical transect (parallel with the hillslope) at approximately $10 \mathrm{~cm}$ intervals, similar to sampling the horizons of a modern soil profile. Large, $\sim 0.2 \mathrm{~kg}$ lithified blocks were removed from the brick-like paleosol surface for mineralogical analyses. The morphology, Munsell color and qualitative calcareousness of samples were also described during collection (Figure 3).

The same paleosol profiles were previously analyzed for bulk geochemistry by Retallack et al. (2000) and those values were used to calculate chemical index of alteration and molar weathering ratios to augment our mineralogical assessment of the same samples (see Results). The three paleosols sampled were a red Alfisol ("Luca" pedotype from Retallack et al. (2000) ${ }^{29}$, a tan Entisol ("Kskus" pedotype), and a brown Inceptisol ("Ticam" pedotype). In modern soil taxonomy, Alfisols are moderately weathered soils typically forming in semi-arid to humid climates under broadleaf temperate forests and are characterized by a clay-enriched subsurface horizon (layer) as well as accumulations of $\mathrm{Al}$ and $\mathrm{Fe}$, lending the "Alf" of Alfisol. Entisols are minimally developed soils which are characterized by a lack of pedogenic horizon development and are generally minimally altered from their parent material. Inceptisols are "new soils" and typically have only weak development of horizons produced by top-down pedogenic weathering ${ }^{32}$. 


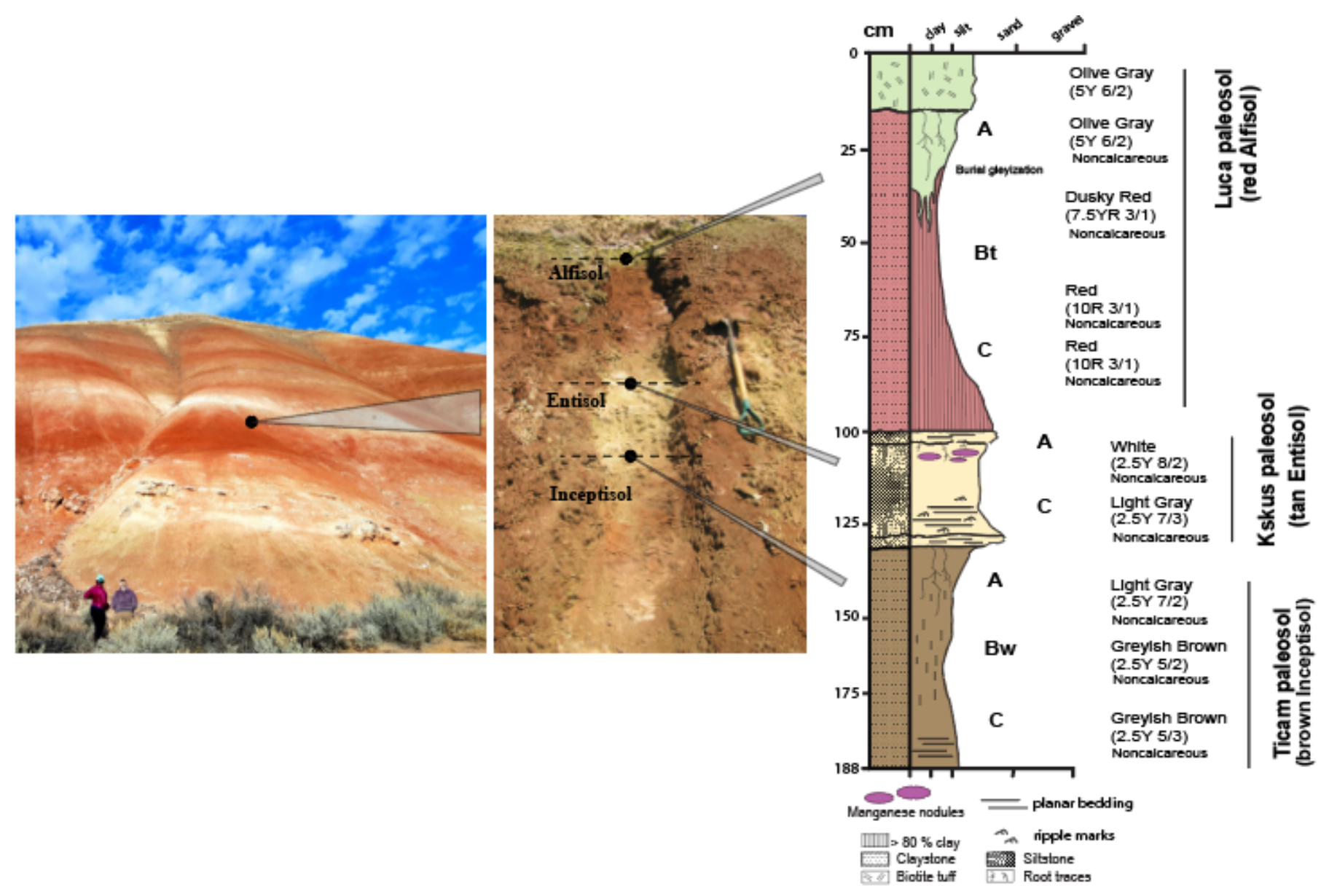

Figure 3. Morphology of three successive paleosols examined in this work. Paleosols are from the early Oligocene (33 Ma) middle Big Basin Member of the John Day Formation in eastern Oregon, USA showing lithology, grain size, horizon designations, and Munsell color. The upper paleosol (red with drab green top) is a moderately weathered Alfisol (Hapludalf in US Taxonomy ${ }^{32}$ ) with a clay-enriched subsurface (Bt) horizon; stratigraphically below is a minimally weathered and weakly developed Entisol with minimal pedogenic horizon development and persistent relict bedding in the subsurface (C) horizon (Fluvent in US Taxonomy, tan color); the lowest soil (brown color) is an Inceptisol with slight enrichment of clay into a weakly-developed subsurface (Bw) horizon (Andic Eutrochrept in US Taxonomy).

\subsection{Visible-near infrared spectroscopy}

Reflectance spectra of paleosols was measured on hand samples collected from the outcrop using a portable ASD QualitySpec Trek spectrometer (Analytik, Cambridge, UK). Reflectance features from $0.35-2.5 \mu \mathrm{m}$ of samples were measured indoors at ambient $\left(25^{\circ} \mathrm{C}\right)$ temperature at the Condon Paleontology Center at the John Day Fossil Beds National Monument, and samples were not ground or sieved before analysis. Dioctahedral clay mineralogy was inferred from cation-OH combination bands in the $2.2-2.5$ um region ${ }^{58}$. Band centers between $2.12-2.21$ microns indicated the presence of Alsmectite. $\mathrm{Fe} / \mathrm{Mg}$ clays and carbonates were identified from absorption bands between 2.27 and 2.36 microns while oxides were identified from bands between $0.75-1.03$ microns. Absorption bands from zeolites are noted across the 2.1-2.5-micron range which overlap with $\mathrm{Si}-\mathrm{OH}$ and/or metal-OH absorption bands in phyllosilicates. Zeolites were identified by the presence of absorption bands at 1.9, 1.4 and $\sim 1.75$ 


\section{This paper is a non-peer reviewed preprint submitted to EarthArXiv}

microns. Spectra were not gathered from the thinnest and least developed paleosol (Entisol), but all three paleosol types were subject to X-ray diffraction and evolved gas analysis, discussed below.

\subsection{X-ray diffraction of paleosol samples}

Paleosols were powdered and homogenized to $<45 \mu \mathrm{m}$ grain size, then unoriented samples were mounted on aluminum holders and measured using a PANalytical X'pert Pro MPD XRD at NASA Johnson Space Center. XRD patterns were collected using an X'celerator detector and Co K $\alpha$ X-ray source, with a Fe filter to reduce $\mathrm{K} \beta$ peak intensities. Samples were analyzed under the following conditions: $45 \mathrm{kV}, 40 \mathrm{~mA}, 1 / 2^{\circ}$ antiscatter slit, $14^{\circ}$ fixed divergence slit, and a beam knife to reduce lowangle scattering. Samples were measured from $4^{\circ}$ to $80^{\circ} 2 \theta$ with a $0.02^{\circ}$ step size at $100 \mathrm{~s} / \mathrm{step}$. Mineral identification was accomplished using HighScore and Jade MDI software by comparing XRD patterns to International Center for Diffraction Data (ICDD) database patterns, and with Crystallography Open Database (COD) patterns.

Semi-quantitative XRD (no internal standard) was used to provide a relative estimate of phyllosilicate abundances. Rietveld refinement ${ }^{59}$ was carried out using MDI Jade Software with initial structure parameters for crystalline phases from the RRUFF database (http://ruff.info/). Background patterns were fit by a polynomial and peaks were modeled by a pseudo-Voigt profile function. Pattern overlays of standard phyllosilicates with known relative intensity ratio (RIR) and full width at half maximum (FWHM) from the Clay Minerals Society ${ }^{60}$ were used in Rietveld refinements to estimate abundances of phyllosilicates in bulk samples. Since no internal standard was used, semi-quantitative XRD was used only for estimating the relative abundances of phyllosilicates in each sample (Table S4).

\subsection{Thermal and evolved gas analysis (EGA) of paleosol samples}

A Setaram Labsys Evo differential scanning calorimeter (DSC) / thermal gravimeter (TG) connected to a Pfeiffer Omnistar quadrupole mass spectrometer (QMS) was configured to operate similarly to the SAM evolved gas analyzer. The Sample Analysis at Mars (SAM) onboard Curiosity Mars Rover does not have TG/DSC capabilities, but these components permit a better understanding of phase transitions and chemical reactions in laboratory experiments. Approximately $50 \mathrm{mg} \pm 3 \mathrm{mg}$ of ground paleosol sample were placed in an $\mathrm{Al}_{2} \mathrm{O}_{3}$ sample crucible which was previously ashed at $500^{\circ} \mathrm{C}$ to remove organic contaminants before use. The sample crucible and an identical empty reference crucible were placed in the furnace and then the system was purged twice with helium gas and then set to a pressure of 30 mbar. Helium was chosen as a carrier gas because it is inert and because it used as a carrier gas in the SAM instrument. The crucibles were heated from approximately $35^{\circ} \mathrm{C}$ to $1000{ }^{\circ} \mathrm{C}$ at a heating rate of $35^{\circ} \mathrm{C} / \mathrm{min}$ and at a flow rate of $10 \mathrm{sccm}$. Volatiles ranging from mass $/$ charge $(\mathrm{m} / \mathrm{z}) 1-100$ were measured. All analyses were performed in duplicate.

Evolved water abundances were determined using a Netzsch TG/DSC coupled to a Pfeiffer QMS. An $\mathrm{Al}_{2} \mathrm{O}_{3}$ sample crucible and an identical reference crucible were placed in the furnace. The instrument was purged twice with ultra-high purity $\mathrm{O}_{2}$ and set to a pressure of 1000 mbar prior to sample analyses to remove any contamination in the system. The crucibles were heated from approximately $35^{\circ} \mathrm{C}$ to $1000{ }^{\circ} \mathrm{C}$ at a heating rate of $35^{\circ} \mathrm{C} / \mathrm{min}$ and at a flow rate of $19 \mathrm{ml} \mathrm{O} / 2 \mathrm{~min}$. A series of three blanks were analyzed before and after each group $(\mathrm{n}=10)$ of samples. A calibration curve for $\mathrm{CO}_{2}$ was created by analyzing a calcite standard (Iceland sparry calcite $40 \mathrm{u} M$ ) at eight sample masses ranging from $0.01-4 \mathrm{mg}$. This calibration curve was used to calculate the amount of $\mathrm{CO}_{2}$ evolved from each sample, and these values were converted to weight percent and subtracted from the thermogravimetric data to estimate mass loss from water evolutions. Oxygen was chosen as a carrier gas because it encourages complete combustion of all organic and inorganic carbon in samples, which indirectly allowed for calculation of evolved water 


\section{This paper is a non-peer reviewed preprint submitted to EarthArXiv}

abundances. Since there were no major overlapping gases with evolved water, mass loss from low amounts $(<0.1 \mathrm{wt} . \%)$ of organic and inorganic carbon were the only significant sources of mass loss aside from water loss from hydrated phases ( $\sim 3-5 \mathrm{wt} . \%)$, so the remaining mass loss after accounting for $\mathrm{CO}_{2}$ evolutions was attributed to evolved $\mathrm{H}_{2} \mathrm{O}$, thus allowing for estimates of evolved water abundances from the thermogravimetric data. All analyses were performed in duplicate.

\subsection{Bulk geochemistry and grain size}

Previously published estimates of bulk geochemistry and grain size were used to augment determination of mineralogy. Retallack et al. (2000) collected oriented paleosol samples for point counting and bulk geochemistry. Point counting (500 points) to determine relative percent of sand, silt and clay size fractions was performed using a Swift automated stage and Hacker counting box fitted to a Leitz Orthoplan Pol research microscope. Accuracy of point counting was determined to be $\pm 2 \mathrm{wt}$. \% for common constituents. Bulk density was also previously determined by the clod method ${ }^{18}$ first by determining raw weight, then weight of clods coated in paraffin of known density $\left(0.86 \mathrm{~g} \mathrm{~cm}^{-3}\right)$ in and out of chilled $\left(6^{\circ} \mathrm{C}\right)$ water $\left(1.00 \mathrm{~g} \mathrm{~cm}^{-3}\right)$. Major element chemistry of paleosols was determined by X-ray fluorescence, atomic absorbance, and X-ray diffraction at Washington State University, Pullman (Table $\mathrm{S} 1)$. These previously published data were used to calculate chemical index of alteration and molar weathering ratios of each paleosol profile examined in this work. Major element chemistry from Retallack et al. (2000) and calculated CIA and molar weathering ratios are both included as supplementary data (Table S1).

\section{Results and Discussion 3.1 Chemical weathering trends}

Trends in molecular weathering ratios across the three paleosol types were attributed to differences in chemical weathering intensity and duration. All profiles showed evidence of hydrolysis of volcaniclastic sediments from increases in alumina/silica and alumina/bases toward the top of profiles (Figure 4). The clay size fraction ranged from 75.0 to $95.4 \pm 2 \mathrm{wt} . \%$ and was greatest in the subsurface (Bt) horizon of the Alfisol and lowest in the surface (A) horizon of the Entisol. Generally low ranges of calcification $\left(\mathrm{CaO}+\mathrm{MgO} / \mathrm{Al}_{2} \mathrm{O}_{3}\right)$ were noted in all three profiles and suggested minimal or absent accumulation of $\mathrm{CaCO}_{3}$. This is characteristic of subtropical to temperate soils receiving annual rainfall of $600-1200 \mathrm{~mm}^{31}$. Pedogenic $\mathrm{CaCO}_{3}$ typically accumulates in arid to semiarid soils where annual evapotranspiration exceeds precipitation ${ }^{61}$ and thus significant $\mathrm{CaCO}_{3}$ accumulation was unlikely for paleosols from the Big Basin Member of the John Day Formation. There were negligible trends in alumina/silica ratios, but declining trends in $\mathrm{Na}_{2} \mathrm{O} / \mathrm{K}_{2} \mathrm{O}$ suggest slight salinization in the uppermost paleosol (Alfisol), although this trend terminated in the surface (A) horizon of the Inceptisol. Salinization, a rough measure of the original salt content of paleosols, is defined by the molar ratio of $\mathrm{Na}_{2} \mathrm{O}$ to $\mathrm{K}_{2} \mathrm{O}$ and results from the deposition and/or precipitation of salts in the original soil. Minimal salinization may have caused the slight increase in this ratio at the surface of the Alfisol, but salinization was likely not severe because there was a lack of domed columnar peds and salt crystals that are characteristic of salt-affected soils and paleosols ${ }^{18,62}$. Lack of carbonate and generally deep weathering inferred from high smectite content is consistent with acidic $\mathrm{pH}$, but low alumina/bases ratio, smectite mineralogy and residual feldspar clasts indicate moderate base saturation across all profiles. A pH of $~ 5.5-7.5$ is characteristic of Alfisols formed in similar climates ${ }^{29}$, but diagenetic fluids can alter the original soil $\mathrm{pH}$ after burial and lithification, thereby obscuring primary $\mathrm{pH}$ values ${ }^{63}$. High oxidation of iron $\left(\mathrm{FeO} / \mathrm{Fe}_{2} \mathrm{O}_{3}=0\right)$ and deeply penetrating root traces indicate soil formation in well-drained settings, though the surface (A) horizon of the Alfisol showed slight gleyization $\left(\mathrm{FeO} / \mathrm{Fe}_{2} \mathrm{O}_{3}>0\right)$ most likely from the onset of chemically reducing conditions shortly after burial. This has been attributed to a diagenetic phenomenon known as burial gleization (discussed in detail in Section 3.5) that typically affects the organic matter-rich surface horizons of rapidly buried paleosols. 


\section{This paper is a non-peer reviewed preprint submitted to EarthArXiv}

The chemical index of alteration (CIA) ranged from 72.1 to 80.8 and generally decreased with depth across the Alfisol and Inceptisol (Figure 4). The highest values (80.8) were in the subsurface clay (Bt) horizon of the Alfisol and lowest (72.1) in the C-horizon of the lowermost Inceptisol. The CIA in clayey paleosols is generally highest in subsurface horizons due to illuvial accumulation of clay minerals during top-down hydrolytic weathering and therefore these horizons are thought to be the most reliable for paleoclimate estimations ${ }^{31}$. In contrast, the unweathered, lowermost $\mathrm{C}$ and $\mathrm{R}$ horizons of paleosols (e.g., saprolite) reflect the characteristics of the soil parent material rather than alteration from weathering, and thus CIA is lower in these horizons. The thinnest and least developed paleosol (Entisol) preserves a parent material of redeposited tuffaceous clayey siltstone that was minimally altered by soil formation, inferred from relict bedding in the C-horizon. The high clay content of this paleosol ( $75 \mathrm{wt}$. \%) was most likely inherited from preexisting soils by sheet erosion or flooding. It is unlikely that the Entisol was developed for long enough to develop characteristics indicative of paleoclimate, and therefore estimations of CIA are unreliable and not shown.
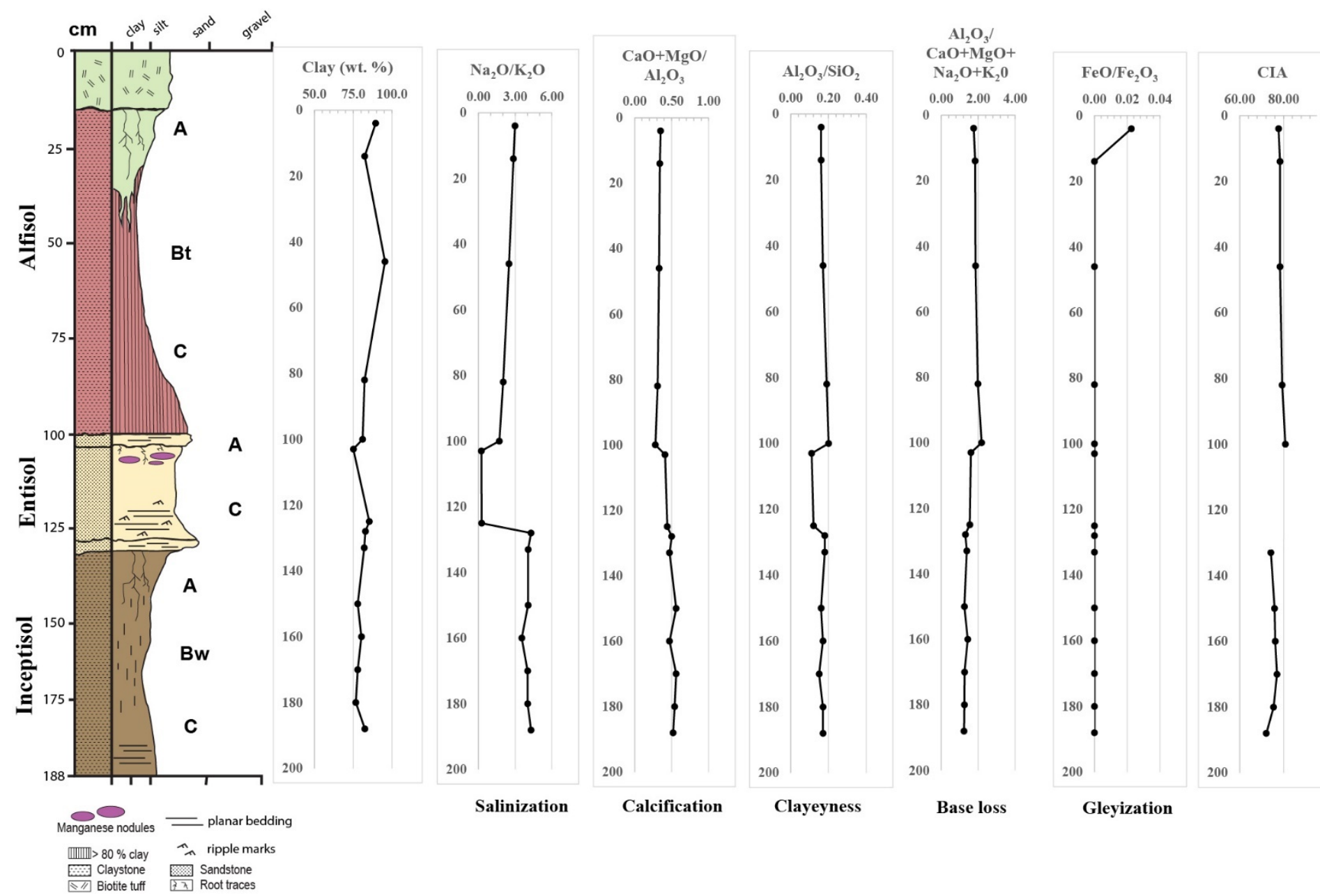
the Oligocene (33 Ma) Big Basin Member of the John Day Formation. CIA = Chemical index of alteration, not shown for the weakly developed Entisol (middle profile). 


\section{This paper is a non-peer reviewed preprint submitted to EarthArXiv}

\subsection{Visible/ near infrared spectroscopy of paleosols}

The mineralogy of paleosols observed with VNIR spectroscopy was dominated by dioctahedral phyllosilicates and occasionally zeolites and hematite. All paleosol samples had strong spectral signatures of 2:1 Al/Fe dioctahedral smectites (Figure 5) and distinct changes in mineralogy were observed within and between paleosol profiles. Spectral absorption bands were consistent with mixtures of Almontmorillonite and Fe-nontronite, and/or Fe substitution in montmorillonite. There were no apparent reflectance features characteristic of trioctahedral smectites such as saponite ${ }^{64}$ or 1:1 smectites such as kaolin group clays ${ }^{58}$.

At the stratigraphically highest location, the near-surface horizon of the Alfisol, characterized by a drab green color, showed strong spectral signatures of Al-smectite with an asymmetric doublet feature centered at 2.22 with shoulders at 2.21 and $2.25 \mu \mathrm{m}$, and a strong water band at $1.92 \mu \mathrm{m}$ (Figures 5 and 6). Band depths of the 1.9 and $2.2 \mu \mathrm{m}$ absorption bands were variable across all samples (Supplementary Data). Al smectites such as montmorillonite have a characteristic band at $2.21 \mu \mathrm{m}$, but the position of this band varies with $\mathrm{Al}-\mathrm{Fe}-\mathrm{Mg}$ abundance, where substitution of $\mathrm{Fe}$ for $\mathrm{Al}$ can cause additional bands at 2.23$2.25 \mu \mathrm{m}{ }^{58}$. A broad absorption band beginning near $2.4 \mu \mathrm{m}$ was consistent with zeolites such as clinoptilolite. Zeolites are likely also responsible for the strong hydration overtone bands at $0.98,1.19$, $1.45,1.78$, and $1.95 \mu \mathrm{m}$, of which usually only the 1.4 and $1.9 \mu \mathrm{m}$ bands are visible in most other hydrated minerals. Diagenetic zeolitization of a poorly crystalline smectite or volcanic glass is thought to have led to the formation of clinoptilolite in paleosols from the John Day Formation ${ }^{29}$. At shorter wavelengths, the sample showed a shoulder at $0.5 \mu \mathrm{m}$ and a strong band at $0.65 \mu \mathrm{m}$ due to $\mathrm{Fe}^{3+}$ in smectite, as well as a broad weak absorption near $1.1 \mu \mathrm{m}$ likely due to $\mathrm{Fe}^{2+/ 3+}$ in smectite ${ }^{40}$.

Stratigraphically lower, the subsurface (Bt) horizon of the Alfisol had much weaker signatures of an $\mathrm{Al}$ smectite with minor amounts of Fe-smectite. (Figure 5). Below this sample, the Alfisol C-horizon had a broad absorption band at $0.9 \mu \mathrm{m}$ attributed to hematite, as well as weak absorption bands of $\mathrm{Al}$ smectite similar to the Bt-horizon. The 0.65 and $0.95 \mu \mathrm{m}$ bands were absent in these samples which was consistent with an absence of Fe-smectite. Hematite in the C-horizon of the Alfisol may have formed from burial dehydration of ferric (oxy)hydroxides (e.g., goethite) which is a common diagenetic alteration in paleosols ${ }^{18}$. Bulk geochemistry of the Alfisol samples indicated lower $\mathrm{Fe}_{2} \mathrm{O}_{3}$ in the surface horizons of samples relative to subsurface horizons (Table S1) which is consistent with VNIR detections of hematite in subsurface horizons.

All samples of the brown colored Inceptisol had spectral signatures of a mixed $\mathrm{Al} / \mathrm{Fe}$ smectite, with a clear band centered at $2.21 \mu \mathrm{m}$, a shoulder at $2.23 \mu \mathrm{m}$, and a weak band at $2.29 \mu \mathrm{m}$, and no detection of hematite. Strong absorption bands near 1.45 and $1.91 \mu \mathrm{m}$ and a shoulder at $2.23 \mu \mathrm{m}$ were consistent with Opal-CT ${ }^{65}$. The light brown Munsell color of this sample $(2.5 \mathrm{Y} 5 / 2)$ was markedly different than the brick-red (10R 7/1) color of the overlying Alfisol and suggests hematite abundances were much lower or absent in the Inceptisol. Sharp 0.65 and $0.95 \mu \mathrm{m}$ Fe smectite absorption bands throughout the profile were consistent with accumulations of nontronite and/or Fe montmorillonite. Like the overlying Alfisol, band depths of the 1.9 and $2.21 \mu \mathrm{m}$ absorption bands were also variable across all samples in the Inceptisol profile (Table S1). 


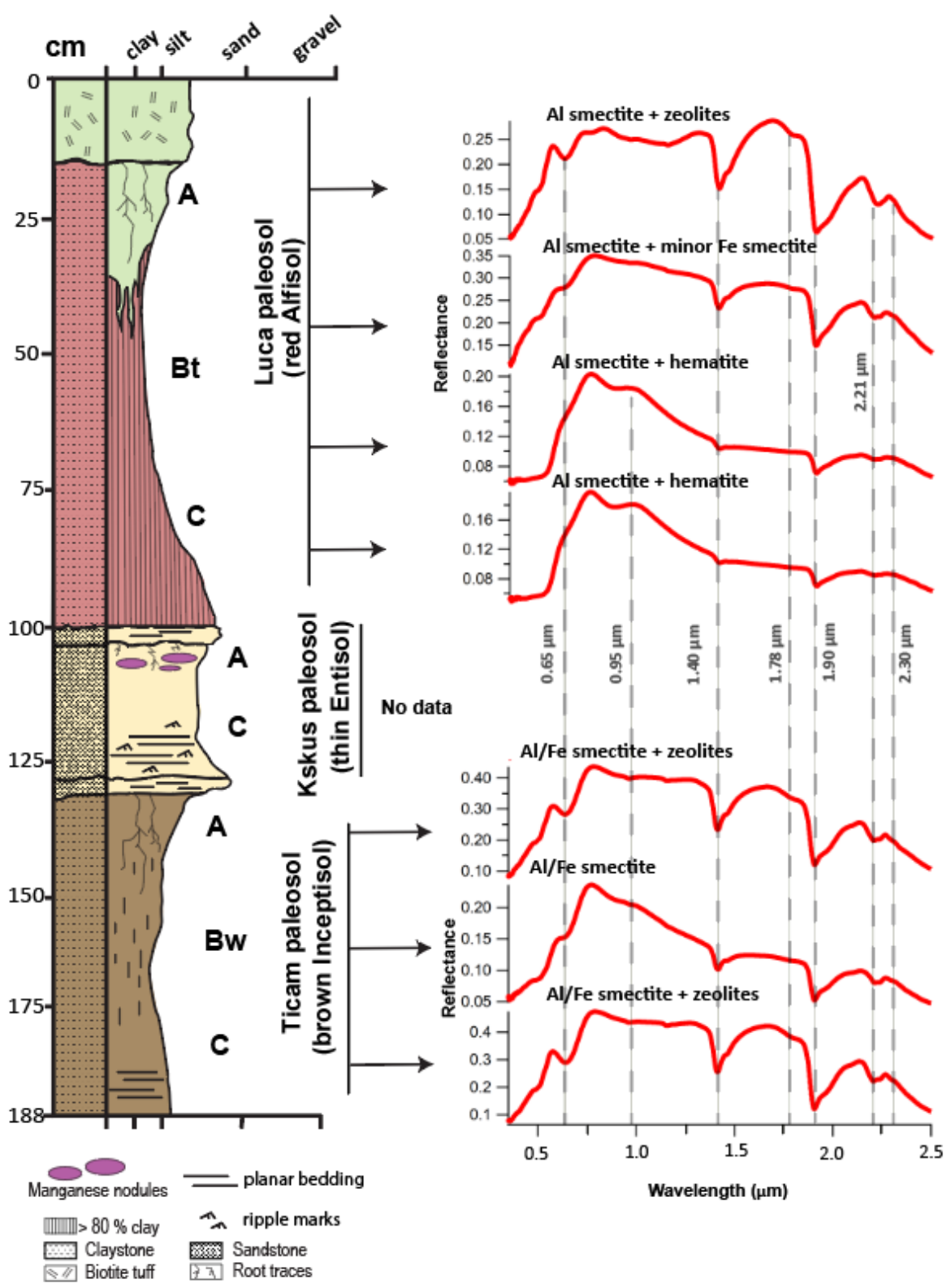

Figure 5. Visible/near infrared reflectance (VNIR) spectra of two paleosols (Alfisol and Inceptisol) from the early Oligocene (33 Ma) middle Big Basin Member of the John Day Formation in eastern Oregon, USA.

The spectral "doublet" feature with bands near 2.21 and 2.23-2.25 $\mu \mathrm{m}$ was observed in all samples and was attributed to $\mathrm{OH}$ stretching and bending combination vibrations in phyllosilicates (Figure 6). Doublet-type spectra typically represent mixtures of various hydrated minerals including kaolinite, Al-smectites and sulfate minerals ${ }^{35,66}$, and previous work has shown that $\mathrm{Fe}^{2+} \mathrm{Fe}^{3+}$ smectites exhibit bands in this region ${ }^{64}$. A doublet feature near 2.21 and 2.23-2.25 $\mu \mathrm{m}$ may be a unique spectroscopic feature of pedogenic smectites that results from isomorphous substitution in the tetrahedral layer of 2:1 phyllosilicates during subaerial weathering. Previous work on smectite-rich mafic soils and paleosols show similar doublet features between 2.2 and $2.3 \mu \mathrm{m}$ that are absent in standard clays ${ }^{58,67}$. The 


\section{This paper is a non-peer reviewed preprint submitted to EarthArXiv}

position and shape of the bands is highly variable, which may result from the isomorphic substitution of large amounts of $\mathrm{Fe}$ for $\mathrm{Al}$ which presumably distorts the crystal structure of clay minerals formed in mafic soils. These doublet features noted in paleosol samples here are similar to doublet features previously observed in paleosols from the John Day Formation ${ }^{67}$. Thus, the doublet features here are consistent with a pedogenic origin for Fe/Al smectites as has been previously suggested ${ }^{67}$, though it should be noted that the phyllosilicate doublet feature has not been observed in silicic soils or other phyllosilicate-rich rocks ${ }^{50,68}$, so absence of the feature is not necessary evidence against a pedogenic origin for clay minerals.

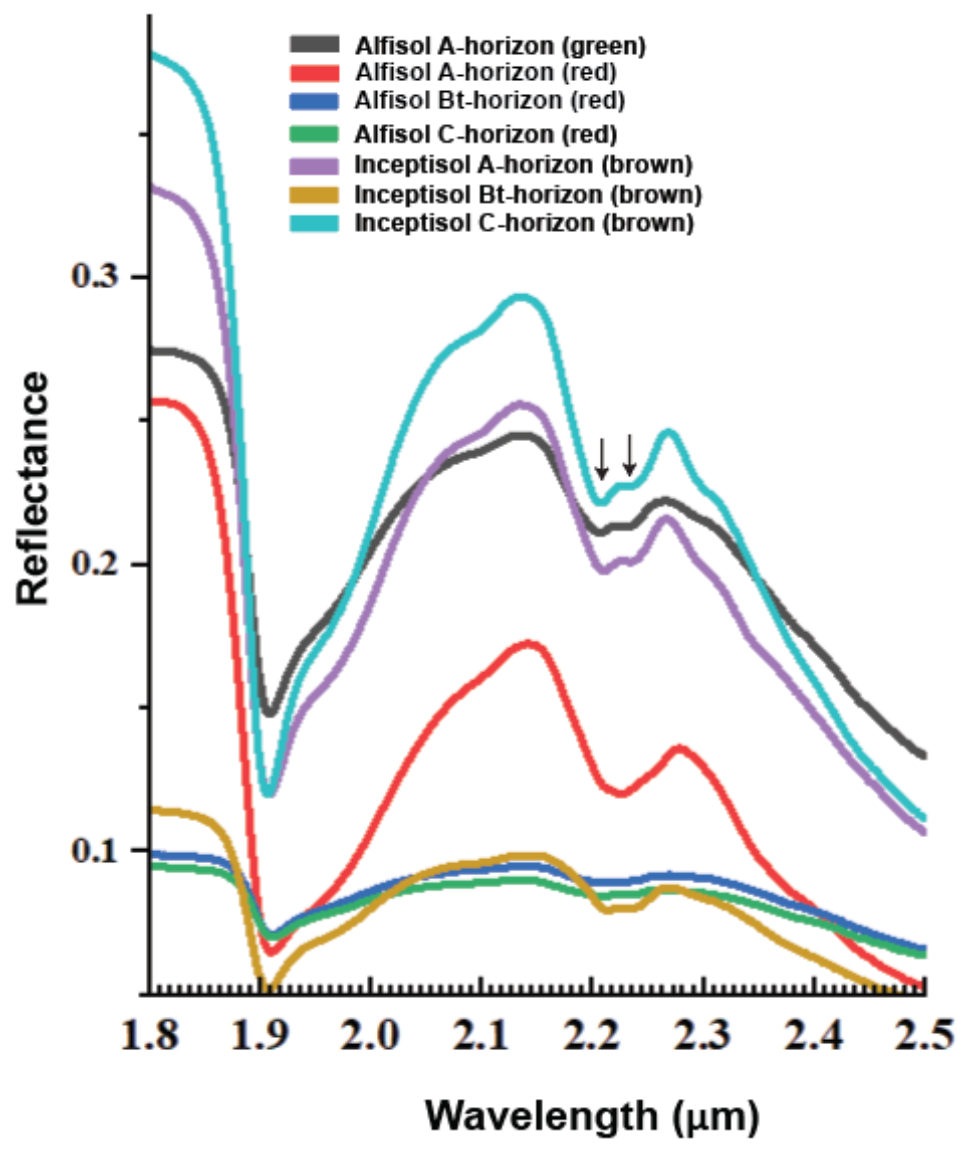

Figure 6. Near-infrared spectra from surface and subsurface horizons of two paleosols (Alfisol and Inceptisol) from the early Oligocene (33 Ma) middle Big Basin Member of the John Day Formation. Spectral doublet feature between 2.2 and $2.23-2.25 \mu \mathrm{m}$ is indicated with black arrows.

\subsection{X-ray diffraction of paleosols}

XRD diffractograms showed strongly crystalline clay minerals dominated all samples (Figure 7, Table 1). Major phases identified in all samples ( $>5 \mathrm{wt}$. \%) were montmorillonite (Al smectite) and nontronite (Fe smectite) while minor phases $(<5 \mathrm{wt} . \%$.) identified from patterns in all samples were clinoptilolite, cristobalite, Opal-CT, quartz, andesine, orthoclase, gypsum and jarosite. Notably, the zeolite mineral clinoptilolite $\left(\mathrm{Na}_{.66} \mathrm{Ca} .{ }_{86} \mathrm{~K}_{.64} \mathrm{Mg} .{ }_{26} \mathrm{Si}_{18} \mathrm{O}_{49.42} \mathrm{H}_{26.4}\right)$ was identified from patterns in all paleosol samples, which likely formed from post-burial alteration of volcanic glass or other poorly ordered phases including smectite during Miocene-age burial recrystallization ${ }^{29}$. 
This paper is a non-peer reviewed preprint submitted to EarthArXiv

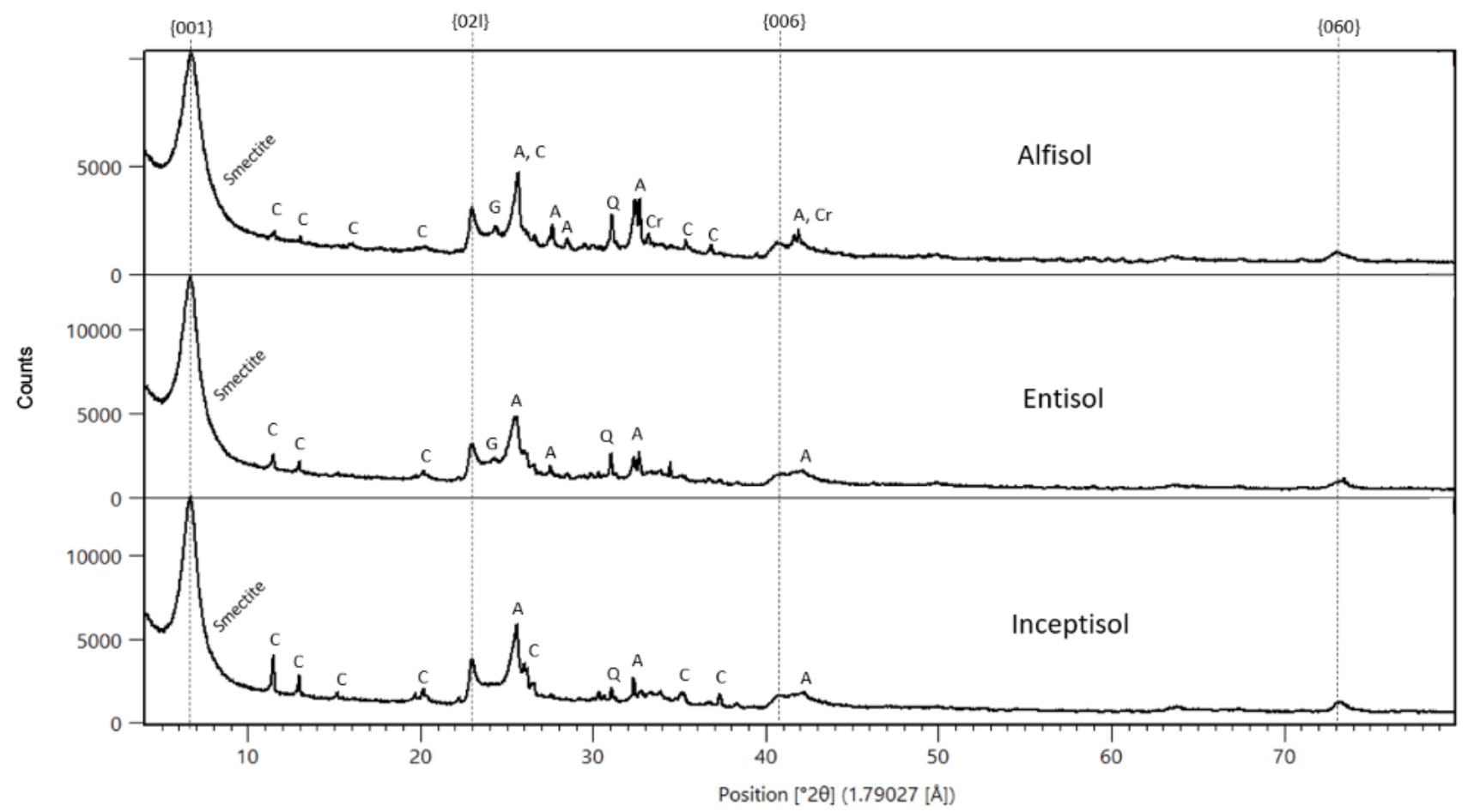

Figure 7. X-ray diffraction patterns from the near surface (A-horizon) of three paleosols from the early Oligocene (33 Ma) middle Big Basin Member of the John Day Formation in eastern Oregon, USA. $\mathbf{S}=$ Smectite; $\mathbf{G}=$ Gypsum; $\mathbf{A}=$ Andesine; $\mathbf{C}=$ Clinoptilolite; $\mathbf{C r}=$ Cristobalite; $\mathbf{Q}=\mathbf{Q u a r t z}$. Highlighted are the 001 and 021 smectite peaks; difference in 021 band position corresponds to a difference in octahedral occupancy.

Beginning with the stratigraphically highest sample (Alfisol $4 \mathrm{~cm}$ ), major phases identified from patterns were montmorillonite and nontronite while minor phases identified were andesine, Opal-CT and cristobalite, with lesser abundances of clinoptilolite, quartz, gypsum, jarosite, and anatase (Figure 7). Stratigraphically below this sample, the Alfisol A-horizon at $14 \mathrm{~cm}$ showed a similar mineral assemblage with the addition of albite as a minor phase (Table 1). A deeper sample of the Alfisol at $46 \mathrm{~cm}(\mathrm{Bt}$ horizon) had montmorillonite and nontronite as major phases and albite, cristobalite, opal-CT, clinoptilolite, hematite, quartz and anatase as minor phases. Directly below, the pattern from Entisol Ahorizon at $7 \mathrm{~cm}$ was consistent with montmorillonite and nontronite as major phases and cristobalite, anatase, clinoptilolite, and orthoclase as minor phases (Figure 7). Stratigraphically below this sample, the pattern for the near-surface $(A)$ horizon of the Inceptisol $(3 \mathrm{~cm})$ showed montmorillonite, nontronite and Opal-CT as major phases and clinoptilolite, cristobalite, andesine, orthoclase, quartz, and gypsum as minor phases. The pattern from the stratigraphically lowest sample, the Inceptisol Bw-horizon at $21 \mathrm{~cm}$, showed the same major phases as the A-horizon $(3 \mathrm{~cm})$ sample, but with the additions of hematite, ilmenite $\left(\mathrm{FeTiO}_{3}\right)$ and anatase along with clinoptilolite, cristobalite, quartz and andesine as minor phases.

Table 1. Summary of major and minor phases detected with $x$-ray diffraction. Major phases $(>5 \mathrm{wt}$. $\%$ are noted with an $\mathrm{X}$ while minor phases $(<5 \mathrm{wt}$. $\%)$ are noted with an asterisk. 


\section{This paper is a non-peer reviewed preprint submitted to EarthArXiv}

\begin{tabular}{|c|c|c|c|c|c|c|c|}
\hline & Alfis ol (4 cm) & Alfis ol (14 cm) & Alfisol (46 cm) & Entis ol (3 cm) & Entis ol (7 cm) & Inceptis ol $(3 \mathrm{~cm})$ & Inceptis ol $(7 \mathrm{~cm})$ \\
\hline Montmorillonite & $\mathbf{X}$ & $\mathrm{X}$ & $\mathrm{X}$ & $\mathbf{X}$ & $\mathrm{X}$ & $\mathbf{X}$ & $\mathbf{X}$ \\
\hline Nontronite & $\mathbf{X}$ & $\mathbf{X}$ & $\mathbf{X}$ & $\mathbf{X}$ & $\mathbf{X}$ & $\mathbf{X}$ & $\mathbf{X}$ \\
\hline Saponite & & & $*$ & & & & \\
\hline Andesite & & $\mathbf{X}$ & & & & $*$ & $*$ \\
\hline Clinoptililite & & * & & * & * & $*$ & $*$ \\
\hline Cristobalite & $*$ & * & $*$ & $*$ & * & $*$ & $*$ \\
\hline Opal-CT & $*$ & $*$ & * & $\mathbf{X}$ & $\mathbf{X}$ & $\mathbf{X}$ & $\mathbf{X}$ \\
\hline Quartz & $*$ & * & * & $*$ & $*$ & $*$ & $*$ \\
\hline Anatase & * & * & * & * & * & $*$ & $*$ \\
\hline Albite & & $\mathbf{X}$ & $\mathbf{X}$ & $*$ & * & & \\
\hline Orthoclase & & & & & * & $*$ & $*$ \\
\hline Hematite & & & * & & & & $*$ \\
\hline Gypsum & $*$ & & $*$ & $*$ & $*$ & $*$ & $*$ \\
\hline Jarosite & * & & & & & & \\
\hline \multicolumn{2}{|c|}{ Others/Amorphous } & & & $*$ & * & $*$ & $*$ \\
\hline
\end{tabular}

The abundance of crystalline clay minerals across all samples is consistent with pedogenic surface weathering of andesitic to rhyolitic tuff / ash under a temperate climate (MAT of $\sim 10^{\circ} \mathrm{C}$ and MAP of 600-1200 mm) over 10-100 Kyr of soil formation ${ }^{29}$. This agrees with other estimates of MAT $>12^{\circ} \mathrm{C}$ and MAP of $>1000 \mathrm{~mm}$ from geochemical climofunctions applied to the subsurface horizons of paleosols from the middle Big Basin Member ( $33.7 \mathrm{Ma})$ of the John Day Formation ${ }^{31}$. This amount of surface weathering over tens to hundreds of thousands of years transformed most volcanic glass to smectite via hydrolytic weathering, potentially leaving only a small x-ray amorphous component (e.g., unweathered volcanic glass and/or poorly ordered phases) which presumably was diagenetically altered via zeolitization to clinoptilolite. There were no XRD detections of illite which suggests minimal or absent potash metasomatism despite burial by an estimated $\sim 2 \mathrm{~km}$ of overburden ${ }^{69}$.

\subsection{Evolved Gas Analysis 3.4.1 $\mathrm{H}_{2} \mathrm{O}$ evolutions}

All samples evolved $\mathrm{H}_{2} \mathrm{O}(\mathrm{m} / \mathrm{z} 18)$ during evolved gas analyses which was attributed to the release of adsorbed water, interlayer water, and water from dehydroxylation in the octahedral layer of a dioctahedral clay mineral (Figure 8). Low temperature $\left(<450{ }^{\circ} \mathrm{C}\right)$ and high temperature $\left(>450{ }^{\circ} \mathrm{C}\right)$ evolutions of water from paleosol samples co-occurred with an endotherm in the heat flow data (dotted line, Figure 8) resulting from endothermic dehydration and dehydroxylation reactions, respectively. Evolved water abundances ranged from $3.24 \pm 0.47 \mathrm{wt} . \%$ to $5.03 \pm 0.12 \mathrm{wt} . \% \mathrm{H}_{2} \mathrm{O}$ across all samples ( $\mathrm{n}$ $=20$ ) and trends in water abundances were apparent across the three paleosols. The Alfisol evolved the lowest amount of water observed with $3.24 \pm 0.47$ in the subsurface $(\mathrm{Bt})$ horizon whereas the Entisol averaged $5.03 \pm 12 \mathrm{wt}$. \% which was the highest amount of evolved water observed in the experiment. The Inceptisol ranged from $4.32 \pm 0.03$ wt. \% to $4.81 \pm 0.13$ wt. $\% \mathrm{H}_{2} \mathrm{O}$ and showed a trend of decreasing abundance with depth. Despite significant differences in evolved water abundances between profiles, each profile generally showed a decrease in evolved water abundance with depth. Though many factors control the abundance and persistence of hydrated phases in paleosols, trends in evolved water abundances could have resulted from lateral and vertical diversity in mineralogy within each of the paleosol profiles.

Water evolutions at temperatures less than $300{ }^{\circ} \mathrm{C}$ were consistent with adsorbed water on mineral surfaces ${ }^{70}$. Evolutions of $\mathrm{H}_{2} \mathrm{O}$ between $100{ }^{\circ} \mathrm{C}$ and $300{ }^{\circ} \mathrm{C}$ can result from the release of interlayer $\mathrm{H}_{2} \mathrm{O}$ from smectite and other 2:1 clay minerals (McAdam et al., 2020) or from dehydroxylation and/or dehydration of poorly crystalline, nanophase or amorphous aluminosilicates such as allophane and imogolite ${ }^{72}$. Nanophase oxides/oxyhydroxides including ferrihydrite can evolve adsorbed $\mathrm{H}_{2} \mathrm{O}$ at temperatures ranges below $\sim 450{ }^{\circ} \mathrm{C}$ due to their high specific surface areas ${ }^{73}$ and could have contributed to water evolutions below $200{ }^{\circ} \mathrm{C}$. Other sources of minor $\mathrm{H}_{2} \mathrm{O}$ evolutions near $300{ }^{\circ} \mathrm{C}$ could be from oxyhydroxides such as goethite which dehydroxylate at temperatures ranging from $280-320^{\circ} \mathrm{C}^{74}$. 


\section{This paper is a non-peer reviewed preprint submitted to EarthArXiv}

Differences in evolved $\mathrm{H}_{2} \mathrm{O}$ peaks $<450{ }^{\circ} \mathrm{C}$ across the three paleosols examined here may have resulted from differences in abundance and composition of x-ray amorphous components. Though amorphous phase composition was not examined in this work, a previous study identified basaltic glass (5.6 wt. \%), allophanes (7.9 wt. \%) and ferrihydrite (0.6 wt. \%) as the dominant amorphous phases in paleosols from the Oligocene ( $28 \mathrm{Ma})$ Turtle Cove member of the John Day Formation (Smith et al., 2018) which are stratigraphically higher than paleosols examined here (Figure 1). Turtle Cove paleosols have mineralogical and paleobotanical evidence of a cool and dry climate of an estimated MAP of 400$600 \mathrm{~mm}$ (Figure 2) and thus minor alteration of volcanic ash and tuff ${ }^{31}$. A SAM-EGA analog analysis of a Turtle Cove paleosol was performed by Smith et al. (2018) ${ }^{72}$ who noted a water release peak at $\sim 290{ }^{\circ} \mathrm{C}$ which was attributed to the abundance $(>\sim 40 \mathrm{wt} . \%)$ of amorphous materials in the sample, unlike the low amount $(<5$ wt. \%) of x-ray amorphous phases found in smectitic paleosols in the middle Big Basin member of the John Day Formation. Paleosols from the Big Basin Member formed under a much warmer (MAT 16-18 ${ }^{\circ}$ ) and wetter (MAP $600-1200 \mathrm{~mm}$ ) climate than those from the Turtle Cove Member and was sufficient to transform amorphous and nanocrystalline phases to $\mathrm{Al} / \mathrm{Fe}$ smectites. In the present study there were no sharp water release peaks at $\sim 290^{\circ} \mathrm{C}$ (Figure 8), possibly because samples are composed primarily of strongly crystalline clay minerals rather than amorphous colloids, especially the Alfisol with up to $95 \mathrm{wt}$. \% clay minerals (Figure 3). However, a minor $300{ }^{\circ} \mathrm{C}$ endotherm in all samples is consistent with small amounts of amorphous phases, which were also detected with XRD as minor phases in the Entisol and Inceptisol (Table 1). In contrast to the moderately weathered Alfisol, the Entisol and Inceptisol were only minimally weathered before burial, inferred from morphological features such as absence of clay illuviation and persistence of relict bedding in subsurface horizons (Figure 3). As such, differences in the duration of weathering before burial can explain the persistence of amorphous phases in the Entisol and Inceptisol and absence of amorphous phases in the Alfisol.

Overall, the preservation of metastable amorphous phases over geological time scales is uncommon in sedimentary rocks; however, recent work has shown that large amounts ( $>40 \mathrm{wt}$. \%) of amorphous colloids have persisted for millions of years in lithified and diagenetically altered volcaniclastic paleosols from the Oligocene ( $28 \mathrm{Ma}$ ) Turtle Cove Member of the John Day Formation ${ }^{19}$. Thus, detections of minor amounts of amorphous phases $(<5 \mathrm{wt} . \%)$ with both EGA and XRD suggest metastable amorphous and/or nanocrystalline phases may have also persisted for $\sim 33 \mathrm{Ma}$ in paleosols from the middle Big Basin Member of the John Day Formation. 


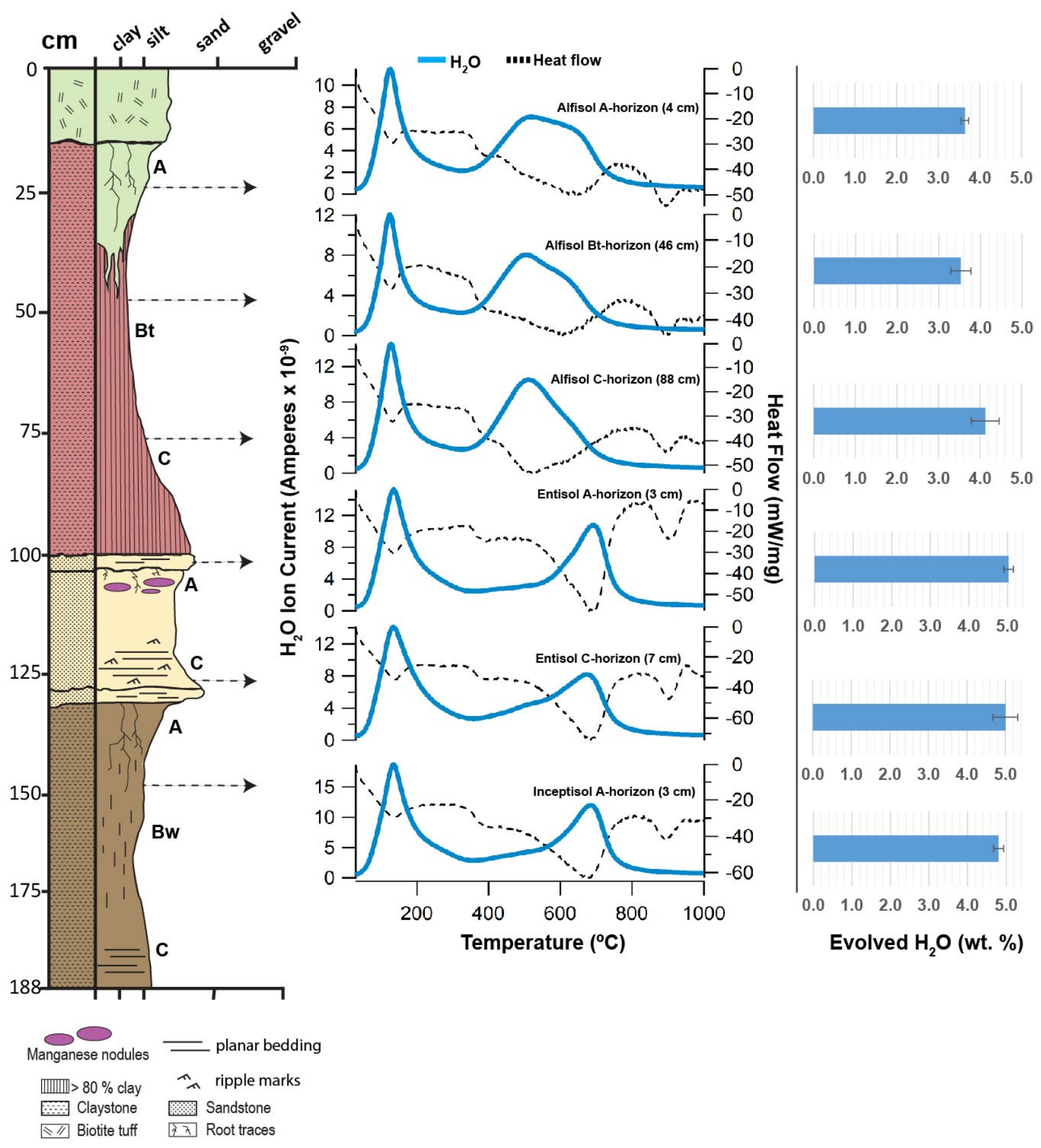

Figure 8. Evolutions of $\mathrm{H}_{2} \mathrm{O}$ from early Oligocene (33 Ma) paleosols from the John Day Fossil Beds National Monument, Oregon. Blue trace is $\mathrm{H}_{2} \mathrm{O}(\mathrm{m} / \mathrm{z} 18)$, and dashed trace is heat flow from differential scanning calorimetry (DSC).

Evolutions of $\mathrm{H}_{2} \mathrm{O}$ above $450^{\circ} \mathrm{C}$ are consistent with the dehydroxylation of the octahedral layer of a 2:1 phyllosilicate ${ }^{71,75}$, and there was a $\sim 200^{\circ} \mathrm{C}$ difference in $\mathrm{H}_{2} \mathrm{O}$ peak release temperature between the three paleosols. The Alfisol with $\sim 95$ wt. \% smectite evolved $\mathrm{H}_{2} \mathrm{O}$ with peaks centered at $\sim 500^{\circ} \mathrm{C}$, while the Entisol ( $\sim 75$ wt. \% smectite) and the Inceptisol ( $\sim 78$ wt. \% smectite) evolved $\mathrm{H}_{2} \mathrm{O}$ with peaks centered at $\sim 700{ }^{\circ} \mathrm{C}$. Differences in clay mineralogy between the soils may be responsible for shifting the 


\section{This paper is a non-peer reviewed preprint submitted to EarthArXiv}

587

588

589

590

591

592

593

594

595

596

597

598

599

600

601

602

603

604

605

606

607

608

609 peaks and shoulders of the high-temperature $\left(>450^{\circ} \mathrm{C}\right)$ evolutions. The considerable difference in peak $\mathrm{H}_{2} \mathrm{O}$ release temperature between the red Alfisol $\left(\sim 500^{\circ} \mathrm{C}\right)$ and the other soils $\left(\sim 700^{\circ} \mathrm{C}\right.$, Figure 8$)$ could have resulted from differences in the occupation of the octahedral sheet of a $2: 1$ phyllosilicate ${ }^{70}$ which leads to differences in the high temperature $\mathrm{H}_{2} \mathrm{O}$ peak release temperature during SAM-EGA ${ }^{76,77}$. Clay minerals with $\mathrm{Fe}$ in the octahedral layer (e.g., nontronite or Fe-montmorillonite) dehydroxylate at a lower temperature $\left(\sim 500^{\circ} \mathrm{C}\right)$ relative to smectite with $\mathrm{Al}$ in the octahedral layer (e.g., Al-montmorillonite, $700^{\circ}$ C ) ${ }^{77}$, though mixed illite-smectite mineralogy also show peak $\mathrm{H}_{2} \mathrm{O}$ release at $698^{\circ} \mathrm{C}$. The Alfisol $\left(\sim 500^{\circ}\right.$ $\mathrm{C}$ peak $\mathrm{H}_{2} \mathrm{O}$ release) exhibited strong VNIR signatures of an Al-smectite with minor Fe-smectite and hematite. The brown Inceptisol $\left(\sim 700^{\circ} \mathrm{C}\right.$ peak $\mathrm{H}_{2} \mathrm{O}$ release) had strong VNIR signatures of an $\mathrm{Al} / \mathrm{Fe}$ smectite and lacked hematite (Figure 5). Differences in clay mineralogy across the samples likely caused the large difference $\left(\sim 200^{\circ} \mathrm{C}\right)$ of peak water release temperatures from smectite dehydroxylation.

Together these results show that EGA in conjunction with XRD and VNIR spectroscopy are suitable techniques to constrain smectite mineralogy in paleosols.

\subsection{2 $\mathrm{SO}_{2}$ evolutions}

All samples evolved minor amounts of $\mathrm{SO}_{2}$ primarily above $450^{\circ} \mathrm{C}$ (Figure 9). Minor $\mathrm{SO}_{2}$ peaks below $400^{\circ} \mathrm{C}$ were observed in the Bt-horizon of the Alfisol and the A-horizon of the Entisol (Figure 9) which most likely resulted from instrument background sources. A distinct $\mathrm{SO}_{2}$ peak at $400^{\circ} \mathrm{C}$ in the Ahorizon of the Entisol is consistent with the presence of minor amounts of sulfides such as pyrite and/or pyrrhotite which thermally decompose at temperatures above $400^{\circ} \mathrm{C}$ under SAM-EGA analog conditions ${ }_{78}^{7}$. Oxidative sulfite decomposition directly to $\mathrm{SO}_{2}$ could have resulted from trace amounts of oxygen in the instrument furnace even after successive purges with helium and are the likely source of the broad $400^{\circ} \mathrm{C} \mathrm{SO}_{2}$ peak noted in the Entisol. 


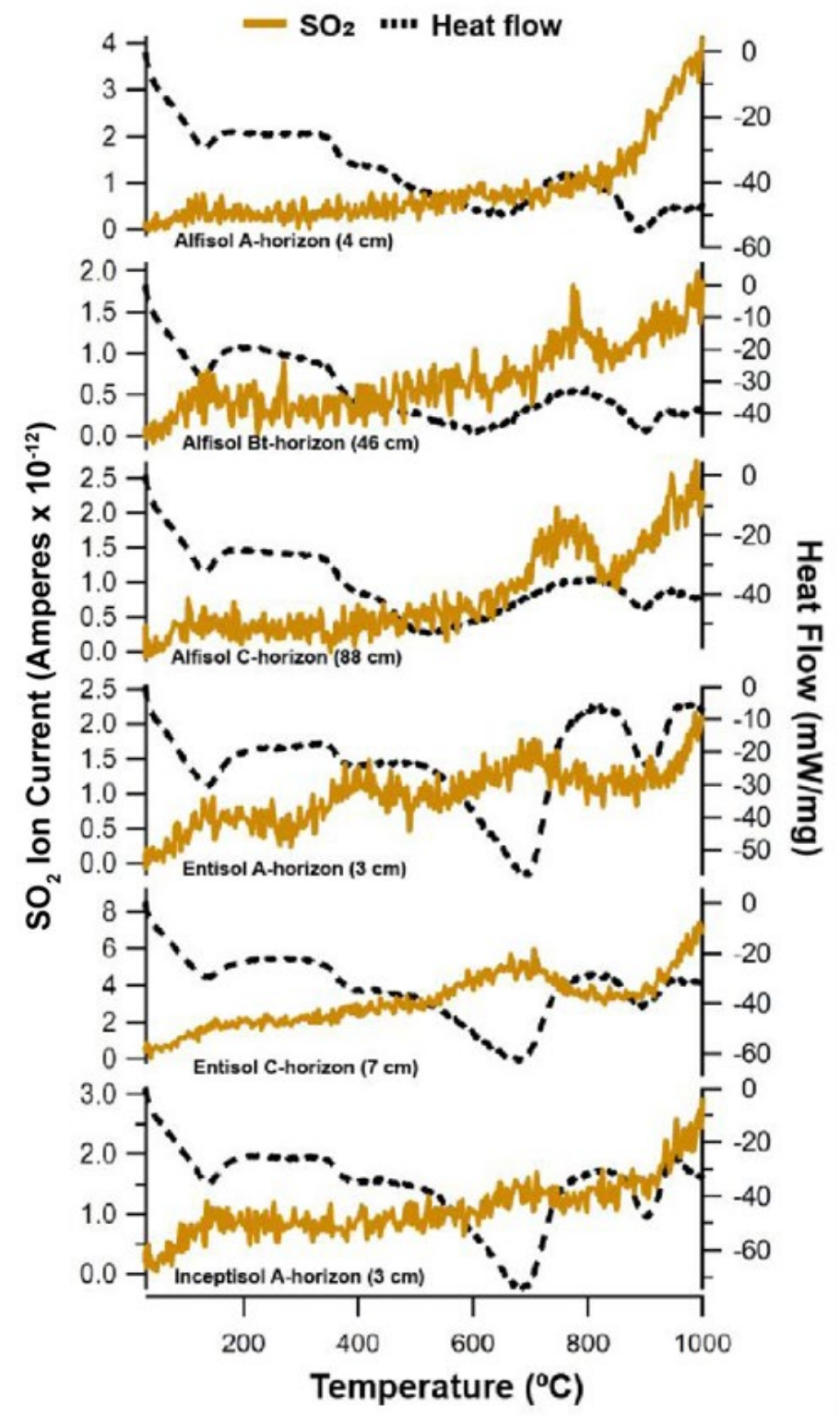

611 Figure 9. Evolutions of $\mathrm{SO}_{2}$ from early Oligocene (33 Ma) paleosols from the John Day Fossil Beds National 612 Monument, Oregon. Yellow trace is $\mathrm{SO}_{2}(\mathrm{~m} / \mathrm{z} 64)$, and dashed trace is heat flow from differential scanning 613 calorimetry (DSC).

Evolutions of $\mathrm{SO}_{2}$ above $500^{\circ} \mathrm{C}$ are consistent with the thermal decomposition of $\mathrm{Ca}$ and $\mathrm{Fe}$ sulfates ranging from crystalline (gypsum and jarosite) to amorphous and/or adsorbed sulfate ${ }^{73,78}$. Also possible are contributions from organo-sulfur compounds and/or $\mathrm{S}$ phase inclusions in volcanic glass. Crystalline sulfate species including jarosite and gypsum have peak $\mathrm{SO}_{2}$ release temperatures near $900^{\circ} \mathrm{C}$ and $1200^{\circ} \mathrm{C}$, respectively ${ }^{74}$. Thus, jarosite and gypsum most likely account for the evolutions of $\mathrm{SO}_{2}$ above $600^{\circ} \mathrm{C}$ and both were confirmed as minor phases with XRD (Table 1). Samples from the Bt and C horizons of the Alfisol had a broad $\mathrm{SO}_{2}$ release with a peak at $\sim 790^{\circ} \mathrm{C}$ that was absent in the Entisol and Inceptisol. Trace amounts of $\mathrm{Mg}$ sulfates in the Alfisol could account for minor $\mathrm{SO}_{2}$ releases $>700^{\circ} \mathrm{C}$ including the $\sim 790^{\circ} \mathrm{C} \mathrm{SO}_{2}$ peaks ${ }^{71,79}$ At higher temperatures, all soils showed a major release of $\mathrm{SO}_{2}$ beginning at $900^{\circ} \mathrm{C}$ which co-occurred with an endotherm, both of which are consistent with the thermal 


\section{This paper is a non-peer reviewed preprint submitted to EarthArXiv}

decomposition of crystalline sulfates ${ }^{75,79}$. Since the samples were only heated to $\sim 1000^{\circ} \mathrm{C}$ for this work, the maximum peak height of this release cannot be ascertained.

The presence of sulfate minerals is uncommon in smectite-rich soils such as those examined here. Sulfate minerals such as gypsum and jarosite tend to form at low $\mathrm{pH}$ and low water:rock ratios whereas pedogenic smectites such as montmorillonite typically form at circumneutral $\mathrm{pH}$ and increased water:rock ratios. Both gypsum and jarosite are unlikely to be original minerals in the paleosols, but more likely formed in the current weathering zone. One possibility for the origin of sulfate minerals in these paleosols is leaching from the modern soils forming atop paleosols (e.g., the weathered paleosol surface). These modern soils that mantle paleosol outcrops have visibly accumulated pedogenic gypsum into a thin $(\sim 1$ $\mathrm{cm}$ ) subsurface gypsic (By) horizon, allowing for their classification as Gypsids (gypsum-rich desert soils) in US Soil Taxonomy ${ }^{32}$. The modern soils are subject to an estimated MAT of $33^{\circ} \mathrm{C}$ and MAP of $290 \mathrm{~mm}$ which is significantly warmer and drier than the estimated conditions during the formation of John Day Formation paleosols (MAT $16-18^{\circ} \mathrm{C}$ and MAP of $600-1,200 \mathrm{~mm}$ ). Sulfate minerals observed with XRD and EGA could have accumulated over time in the underlying paleosols and therefore it is likely that the modern Gypsic soils forming atop paleosol outcrops are the source of sulfate minerals observed here.

\subsection{Diagenetic Alteration}

Diagenetic alterations, or alterations after burial, are common in paleosols. By definition, soils are an early diagenetic alteration because water-rock interactions during pedogenesis alters the physical and chemical properties of sediments. After burial, however, soils are subject to additional early and late diagenetic alterations ranging from minor (e.g., decomposition of organic matter) to severe (e.g., metamorphic alteration). Four types of alteration after burial that have affected paleosols examined in this work are 1) Drab olive-green surface horizons attributed to burial gleization; 2) brick-red color from burial-induced dehydration of ferric hydroxide minerals; 3) zeolitization of volcanic glass and/or poorly crystalline phases; and 4) significant mechanical compaction.

Burial gleization, also known as gley overprinting ${ }^{80}$, has been envisaged as the chemical reduction of iron oxides and hydroxides by anaerobic bacteria in the near-surface horizons of paleosols and is thought to occur shortly after soil burial ${ }^{81,82}$. Burial gleization is an early diagenetic process in paleosols which involves the reduction of $\mathrm{Fe}^{3+}$ to $\mathrm{Fe}^{2+}$ in clays, oxides and other minerals after rapid burial, and promotes anaerobic decay of organic matter ${ }^{18}$, even in soils that originally formed under oxidizing conditions before burial. Typical burial gleization is closed system alteration, without depletion of total iron, and is usually limited to the surface (A) horizons where organic matter is most concentrated. The surface (A) horizon of the uppermost paleosol (Alfisol) examined in this work showed classic evidence of burial gleization with drab-colored mottles and tubular features predominantly in the Ahorizon with minor radiation downward into the subsurface (Bt) horizon (Figure 3) as well as accumulations of $\mathrm{Fe}^{2+}$ exclusively in the A-horizon (Table S1). Spectroscopic techniques such as VNIR employed here can readily identify burial gleization by observing absorbance features attributed to $\mathrm{Fe}^{2+}$ in the surface horizons of paleosols. This was presumably the cause of the broad 1.1-micron $\mathrm{Fe}^{2+}$ band in the surface of the Alfisol, and the shoulders at 2.23-2.25 microns noted in the gleyed surface horizon of the Alfisol (Figures 5 and 6).

Burial gleization can be distinguished from other original redoximorphic features such as groundwater alteration because it is limited to the surface $(\mathrm{A})$ horizon unlike the gleyed subsurface $(\mathrm{Bg})$ horizons of seasonally or perennially waterlogged soils, and because the mineralogy and morphology of this soil provide evidence of well-drained and oxidizing conditions during soil formation. Morphological evidence of burial gleization in paleosols is a drab greenish-gray color exclusively in near-surface horizons directly below the burial contact ${ }^{82}$. Geochemical evidence of burial gleization can include depletions of $\mathrm{Fe}^{3+}$ coupled with increases in $\mathrm{Fe}^{2+}$ and the formation of siderite and pyrite. Most soils accumulate organic matter in near-surface horizons, which after burial and the onset of anoxic conditions is generally the horizon most affected by burial gleyization. Though the timing of burial gleization 


\section{This paper is a non-peer reviewed preprint submitted to EarthArXiv}

remains poorly constrained, reduction haloes around buried organic matter such as roots can form in tens to hundreds of years after burial ${ }^{83}$. In the Alfisol, burial gleyization can be distinguished from groundwater alteration because it is limited to the surface horizon directly below the white biotite-bearing tuff layer which buried the uppermost soil (Figure 3). The original color of the surface horizon of the Alfisol was most likely brown and darkened by accumulation of organic matter. Burial gleization thus indicates the surface horizon of the Alfisol may be enriched in organic matter relative to unaffected subsurface horizons (Bt and $\mathrm{C}$ horizons), but burial degradation of organic carbon over geological time scales has likely reduced the original organic carbon content by up to two orders of magnitude ${ }^{43}$.

Directly below the drab surface horizon, the remainder of the Alfisol profile was brick-red in color (Figure 3, Munsell 10R 3/1) which most likely resulted from dehydration of iron oxyhydroxides ${ }^{84}$. This phenomenon, also known as "burial reddening", is one of the most common types of diagenetic alteration in the fossil record of soils on Earth ${ }^{18,81}$. Diagenetic dehydration of oxyhydroxides such as goethite and ferrihydrite forms strongly crystalline hematite which leads to reddening of soils that are originally brown or yellow in color; however, there is little information about the specific temperatures and pressures at which dehydration reactions occur ${ }^{84}$. Such a deep red color is unlikely to be the original color of the Alfisol because comparable modern Alfisols with smectite mineralogy are brown to yellow in color ${ }^{31}$. Brown and yellow weakly to moderately developed Eocene paleosols from Antarctica also have deep red hues attributed to burial dehydration of ferrihydrite and goethite ${ }^{84}$. Some of the kaolinitic and lateritic paleosols in the Clarno and lower John Day Formations show evidence of deep weathering comparable to modern tropical soils that are red in color; however, soils that are not so deeply weathered such as the Alfisol examined here also have a brick-red color which is consistent with burial reddening. Other factors which cause reddening of paleosols include heating by lava flows ${ }^{85}$ which can also cause iron oxyhydroxides to dehydrate to hematite and maghemite, but the effects of reddening are typically limited to the near-surface horizons due to the thermal insulation properties of soils ${ }^{86}$. Another possibility is that the protolith of the soil was red in color, but relict bedding and volcanic shards in the subsurface (C) horizon (Figure 3) imply a tuffaceous parent material unlikely to be red in color.

The presence of clinoptilolite detected with XRD in all samples (Table 1) suggests zeolitization has pervasively altered paleosols from the John Day Formation. Though zeolites can form in alkaline volcanic soils ${ }^{87}$, a diagenetic origin for clinoptilolite is likely because zeolites are commonly destroyed by hydrolysis during original soil formation, especially in the case of the moderately weathered, smectiterich Alfisol. There are two proposed mechanisms of zeolitization to the John Day Formation paleosols. First, the aqueous flushing model by Hay (1963) ${ }^{88}$ proposed that volcanic glass in the lower John Day Formation was diagenetically altered to zeolites by open-system interactions with groundwater that added $\mathrm{Ca}$ and $\mathrm{H}_{2} \mathrm{O}$ while removing Si, $\mathrm{Na}$ and $\mathrm{K}$. Zeolitization may have occurred during early Miocene deep burial at depths of 380-1200 meters and temperatures of $27-55^{\circ} \mathrm{C}$ during deposition of the overlying Mascall and Rattlesnake Formations. Though the timing of zeolitization is well constrained, the mechanism of alteration by aqueous flushing is not likely because many silty tuff beds in the John Day Formation escaped zeolitization while the clay mineral-rich paleosols did not ${ }^{29}$. These permeable silty tuff beds would have presumably been channels for groundwater, but they include both zeolitized and non-zeolitized segments along strike, suggesting a more localized or patchy distribution of zeolitized facies. These observations are consistent with the hypothesis that some tuffs and paleosols were subject to zeolitization, while others were not.

Rather than zeolites forming from groundwater alteration, diagenesis may have been more localized and the formation of clinoptilolite may have instead resulted from burial-induced recrystallization of amorphous colloids and/or volcanic glass ${ }^{89,90}$. The "burial ripening" model of Retallack (2000) ${ }^{29}$ for zeolitization of paleosols is supported by observations of only small differences between abundances of alkali and alkali earths in paleosols most altered by zeolitization (the Turtle Cove Member paleosols) when compared with minimally altered tuffs. The stepwise increase in alkali and alkali earths in paleosols from the lower John Day Formation to the upper Turtle Cove Member most likely resulted from decreases in weathering intensity during climatic cooling and drying and is independently supported by soil morphological and paleobotanical evidence of cooling and drying ${ }^{28,29}$. Altogether these lines of evidence 


\section{This paper is a non-peer reviewed preprint submitted to EarthArXiv}

support the ripening model for zeolitization which led to localized formation of clinoptilotile from burialinduced crystallization of volcanic glass and/or amorphous colloids. The mechanism(s) of zeolitization are important for interpreting paleosols of the middle John Day Formation including those examined here because their chemical composition would be pervasively altered by the aqueous flushing model, whereas by the burial ripening model their original chemical composition would not have been significantly altered ${ }^{29}$.

Paleosols from the lower John Day formation are buried by approximately 2 kilometers of overburden which has led to significant mechanical compaction. Burial of soil most often results in compaction of void spaces, fossils and pore water. In clayey soils such as those examined here, compaction of originally loose soil peds creates a complex pattern of slickenslides with random orientation that resembles slickenslides in modern smectitic soils with high shrink-swell capacity (Vertisols in US Taxonomy). Paleosols from the John Day Formation are geologically young enough to allow for comparisons with standard compaction curves for sedimentary rocks. Individual profiles from the middle Big Basin Member are covered by an additional $499 \mathrm{~m}$ of John Day formation, $305 \mathrm{~m}$ of Columbia River Basalt, up to $605 \mathrm{~m}$ of Mascall Formation, and $244 \mathrm{~m}$ of Rattlesnake Formation. From this overburden, compaction of paleosols can be estimated using the compaction curve of Sclater and Christie (1980) ${ }^{91}$ and are compacted to an estimated $\sim 70 \%$ of their original thickness, which would suggest an original thickness of about $1.3 \mathrm{~m}$ for the uppermost Alfisol profile, $0.4 \mathrm{~m}$ for the Entisol profile, and $1.3 \mathrm{~m}$ for the lowermost Inceptisol profile.

\subsection{Implications for Mars}

Paleosols at the John Day Fossil Beds National Monument have been proposed to be comparable with putative weathering profiles on Mars because of similarities in mineralogy, morphology and stratigraphy ${ }^{15,20,26,43}$. These sedimentary rocks can be used to help interpret the alteration history of sedimentary rocks on Mars. Work on terrestrial paleosols presented here have implications for a) interpreting orbital remote sensing data for the pedogenic/diagenetic history of sedimentary rocks on Mars, b) constraining climate and habitability from Martian weathering profiles, c) interpreting in-situ results from Martian weathering profiles, and d) biosignature preservation in paleosols.

Orbital VNIR spectra can be compared with VNIR spectra from terrestrial paleosols to evaluate the pedogenic and diagenetic history of ancient sedimentary rocks on Mars. In-situ VNIR spectroscopy of multiple individual paleosol profiles presented here provides a reference frame for evaluating a pedogenic alteration hypothesis for ancient sedimentary rocks on Mars. Though pedogenic processes may have been ubiquitous across the surface of early Mars ${ }^{6}$, it is currently unclear from orbital VNIR spectroscopy if weathering sequences formed from continuous pedogenic alteration (e.g., a deep weathering profile) ${ }^{24,51}$, or if multiple episodes of alteration followed by burial occurred (e.g., repeated episodes of volcanic ash deposition, subaerial weathering, and burial) ${ }^{14}$. The latter formation mechanism is characteristic of paleosol sequences that are composed of hundreds of individual paleosol profiles ${ }^{18}$ such as the Oregon paleosol sequence examined in the present study. At Mawrth Vallis, meter-scale relict bedding of the middle ( $\alpha 2)$ Al-smectite stratigraphic unit at Muara Crater ${ }^{24}$ is consistent with a paleosol sequence hypothesis, though previous work has considered this unit part of a single, massive ( $200 \mathrm{~m}$-thick) deep weathering profile ${ }^{24}$. However, the apparent relict bedding of dark-toned layers in the $\alpha 2$ unit ${ }^{38}$ would presumably be destroyed if the entire deposit was a deep weathering profile. Vertical changes in mineralogy at Muara Crater are consistent with changes in climate, weathering intensity and geochemistry rather than top-down leaching of acidic and reducing fluids through hundreds of vertical meters of stratigraphy. Furthermore, the resolution of CRISM poses challenges for distinguishing between a paleosol sequence and a deep weathering profile. The orbital remote sensing resolution of CRISM (typically $18 \mathrm{~m} /$ pixel) ${ }^{5}$ is much coarser compared to our in-situ VNIR observations (sub-meter scale), which perhaps makes groups of individual paleosol profiles appear as "units" with similar mineralogy. Observations of the Oregon paleosol sequence suggest that changes in climate (e.g. Eocene-Oligocene cooling and drying) led to stratigraphic changes in mineralogy rather than the intense and uninterrupted 


\section{This paper is a non-peer reviewed preprint submitted to EarthArXiv}

814

815

816

817

818

819

820

821

822

823

824

825

826

827 leaching that is characteristic of a deep weathering profile. Instead, the Oregon paleosol sequence reflects a cycle of continuous soil formation and burial that occurred during $\sim 15$ million years of climate change. These changes are reflected in the tens of individual paleosol profiles composing the basal $\mathrm{Fe} / \mathrm{Mg}$ smectite and oxide unit (Clarno Formation, Figure 1) that are overlain by hundreds of individual profiles with $\mathrm{Al} / \mathrm{Fe}$ smectite mineralogy in the middle unit (Big Basin Member, John Day Formation) which are subsequently overlain by hundreds of profiles dominated by nanophase/amorphous Al and Si materials, hydrated silica, calcite and celadonite in the upper unit (Turtle Cover Member). This type of climate change and repeated soil formation may explain the compositional stratigraphy at Muara Crater, which currently stands as the best example of a putative paleosol sequence on Mars.

The examination of Mars-analog paleosols presented here can also help interpret the nature of aqueous alteration of rocks by future rover missions. Data from in-situ investigation of putative Mars weathering profiles can be compared to spectral and morphological features observed in this study to constrain the pedogenic and diagenetic history. Pedogenic features observed in this work included strong VNIR absorbance bands characteristic of dioctahedral Al and Fe smectites; changes in clay mineralogy with depth, primarily observed in the 2.1-2.5 micron range; illuvial accumulation of clay minerals into subsurface $(\mathrm{Bt})$ horizons; destruction of sedimentary bedding in weathered upper layers $(\mathrm{A}$ and $\mathrm{B}$ horizons); preservation of relict bedding in unweathered bottom layers ( $\mathrm{C}$ horizons); and centimeter-scale changes in color and composition. These are all diagnostic features of terrestrial soils and should be considered permissive evidence of pedogenic alteration on Mars. Spectral features of diagenetic alterations included absorbances characteristic of zeolites and hematite. On Mars, these may indicate zeolitization and burial dehydration of iron (oxy)hydroxides, respectively. These and other forms of diagenesis are common in terrestrial paleosols that formed from weathering of volcaniclastic sediments ${ }^{18}$ and may also explain occurrences of zeolites ${ }^{92}$ and hematite ${ }^{51}$ detected from orbit in putative weathering sequences on Mars.

This study provides a protocol for constraining climate and habitability from the geochemistry of weathering profiles on Mars. Molecular weathering ratios that have been well studied in terrestrial paleosols (e.g. ${ }^{31,93}$ ) could be useful for interpreting climate and habitability of weathering profiles on Mars. By using a suite of molecular weathering ratios and geochemical climofunctions (Figure 4), a reconstruction of the climate and nature of weathering can be inferred from weathering profiles on Mars. However, differences in the nature of weathering and diagenesis between Earth and Mars present challenges for making direct comparisons. Such differences include a presumably anoxic early Mars atmosphere that perhaps led to $\mathrm{Fe}^{2+}$ mobility during subaerial weathering ${ }^{24}$, and the apparent absence of plate tectonics which has implications for the nature and severity of diagenesis of weathering profiles on Mars ${ }^{3,94}$. One additional consideration is application of the chemical index of alteration to weathering profiles on Mars that were subject to weathering by acidic and sulfur-rich fluids. Weathering indices such as CIA may not accurately reflect acid sulfate weathering of mafic $\mathrm{Fe} / \mathrm{Mg}$ rich sediments because weathering rates of mafic materials such as olivine proceeds more efficiently than feldspars, especially under acidic conditions ${ }^{95}$. In addition, acidic conditions also affect the mobility of alkaline elements which may further confuse interpretations of weathering intensity by examining CIA ${ }^{51}$. Martian weathering profiles that were alterated by fluids with circumneutral $\mathrm{pH}$ are better candidates for application of molecular weathering ratios, weathering indices, and geochemical climofunctions commonly applied to terrestrial paleosols.

The mineralogy and diagenetic alteration of paleosols also has implications for biosignature preservation in Martian weathering profiles. Biosignatures in paleosols can include biomarkers, biominerals, macro and microstructures and textures, chemistry, and isotopes ${ }^{26}$, and the rapid burial that characteristically entombs paleosols often creates favorable taphonomic environments for the preservation of biosignatures. However, the preservation of chemical and isotopic biosignatures often relies on the bulk abundance of organic matter preserved in a sample. Many factors contribute to the preservation and degradation of organic matter in terrestrial paleosols including redox state prior to burial, clay mineralogy, amorphous phase compositions and abundance, diagenetic alterations, and interactions with sulfur (e.g., sulfurization) ${ }^{15,43}$. Redox state provides a first-order control on the preservation of organic 


\section{This paper is a non-peer reviewed preprint submitted to EarthArXiv}

carbon in rapidly buried soils ${ }^{43}$; for example, soils forming under reducing conditions (e.g., wetlands) generally preserve higher abundances of organics relative to those forming in oxidized, well-drained conditions. Oxidized and Al-smectite rich paleosols such as those examined here are associated with longer organic carbon residence time relative to kaolin group clays ${ }^{96}$, but well-drained, oxidizing conditions before burial are associated with severe losses of organic $\mathrm{C}$ after burial ${ }^{18,43}$. In addition, most types of diagenetic alterations commonly observed in terrestrial paleosols are associated with the degradation of organic matter. Illitization, zeolitization and celadonization may facilitate desorption of organic carbon held on mineral surfaces, interlayer spaces, and crystal edges, thus possibly contributing to burial-induced degradation of organic matter ${ }^{97,98}$, though several authors have reported that early diagenetic smectite-illite transformation may be facilitated by microbes ${ }^{98-100}$ which has implications for biosignature preservation in illite-rich soils. In this work, illitization and celadonization of smectite was not observed, but zeolitization of amorphous colloids and/or poorly crystalline smectite may have liberated adsorbed or chemisorbed organic carbon ${ }^{101}$ and likely contributed to the degradation of the bulk organic fraction. One the other hand, diagenetic features of paleosols such as burial gleization observed in this work (Table S1 and Figure 3) may indicate organic carbon enrichment and the preservation of chemical biosignatures in the surface horizons of paleosols. The drab green surface layer of the uppermost paleosol examined in this work showed an accumulation of $\mathrm{Fe}^{2+}$ attributed to diagenetic burial gleization via anaerobic microbial decay of organic matter. Previous investigations showed that this gleyed layer was enriched in organic carbon relative to deeper layers in the paleosol ${ }^{43}$, and thus burial gleization features most likely constitute a chemical biosignature in paleosols. If features resembling burial gleization are detected in upper layers of weathering profiles on Mars, they should be considered a highpriority location for in-situ biosignature investigation.

\section{Conclusions}

The objective of this study was to analyze the mineralogy and diagenetic alterations of paleosols from eastern Oregon, USA using techniques similar to those utilized by current and future missions to Mars. Samples were gathered from three successive paleosol profiles in the early Oligocene (33 Ma) middle Big Basin Member of the John Day Formation that formed from pedogenic weathering of volcanic ash and tuff. Visible/near infrared spectroscopy, X-ray diffraction and evolved gas analysis confirmed dioctahedral smectite was the major phase in all samples, with most samples primarily containing a mixture of montmorillonite ( $\mathrm{Al}$ smectite) and nontronite (Fe smectite). Minor phases detected with x-ray diffraction included Opal-CT, cristobalite, andesine and gypsum. All samples contained minor amounts of the zeolite mineral clinoptilolite which most likely formed from the diagenetic Ostwald ripening of amorphous or nanocrystalline phases such as allophane, imogolite and/ or poorly crystalline smectite. Across all samples only minor $(<5 \mathrm{wt}$. \%) abundances of amorphous phases were observed; instead, most samples contained between $70-95$ wt. \% crystalline clay minerals.

The mineralogy and morphology of paleosols examined here is consistent with formation under well-drained, oxidizing conditions with moderate weathering rates. Geochemical climofunctions based on molecular weathering ratios applied to these paleosols indicate soil formation under mean annual precipitation of $\sim 600 \mathrm{~mm}$ and mean annual temperature of approximately $10^{\circ} \mathrm{C}$. Pedogenic weathering of volcanic ash under these climatic conditions was sufficient to transform volcanic glass and amorphous/nanocrystalline phases into strongly crystalline dioctahedral clay minerals.

Four types of alteration after burial that have affected paleosols examined in this work are 1) Drab green surface horizons due to burial gleization of organic matter; 2) brick-red color from burialinduced dehydration of ferric oxides and hydroxides; 3 ) zeolitization of volcanic glass and/or poorly crystalline phases; and 4) significant mechanical compaction. Burial gleization, limited to the surface horizons of paleosols, was most likely an early diagenetic alteration that resulted from the chemical reduction of iron hydroxides and oxides by anaerobic bacteria consuming buried organic matter at or below the water table. The timing of burial dehydration of (oxy)hydroxides remains poorly constrained, but late diagenetic alterations such as zeolitization may have occurred during early Miocene burial at 


\section{This paper is a non-peer reviewed preprint submitted to EarthArXiv}

depths of 380 to 1200 meters and temperatures of $27-55^{\circ} \mathrm{C}$ during deposition of the overlying Mascall and Rattlesnake Formations. The current overburden of $\sim 2 \mathrm{~km}$ has also resulted in the mechanical compaction of paleosol profiles to approximately $70 \%$ of their original thickness before burial. Despite significant overburden, absence of illite/chlorite and celadonite imply a lack of diagenetic K-metasomism and celadonization, respectively. The high clay mineral content (up to $95 \mathrm{wt}$ \%) of paleosols from the middle Big Basin Member of the John Day Formation may have insulated profiles from diagenetic alterations which have pervasively altered stratigraphically higher and less clay mineral-rich ( $40 \mathrm{wt} . \%)$ paleosols in the overlying Turtle Cove member of the John Day Formation.

On Mars, there are distinct stratigraphic changes in clay mineral and amorphous phase abundance in sedimentary rocks across the Mawrth Vallis region and these general stratigraphic trends are observed in the eastern Oregon paleosol sequence. Mineralogical changes across the compositional stratigraphy at Muara Crater, Mawrth Vallis are comparable to the up-section decline in crystalline clay minerals and subsequent increase in Al smectite, amorphous phases and hydrated silica through the Clarno and John Day Formations resulting from the aridification of eastern Oregon during the late Eocene and Oligocene. Strong spectral signatures of a nanophase aluminosilicate consistent with allophane and /or imogolite have been noted at the stratigraphically highest layers across the Mawrth Vallis region and are thought to represent a cool and dry climate where nanophase aluminosilicates resulted from minor alteration of volcanic ash ${ }^{40}$, and these uppermost layers share mineralogical similarities with the Turtle Cove Member paleosols. In contrast, the lowermost layers at Mawrth Vallis have strong spectral signatures of crystalline $\mathrm{Fe} / \mathrm{Mg}$ smectite and are perhaps more akin to deeply weathered paleosols from the Clarno and lower John Day Formations.

Pedogenic features observed in this work include dioctahedral smectite mineralogy, a clay mineral doublet feature observed with VNIR spectroscopy possibly resulting from isomorphous substitutions during pedogenic weathering, destruction of sedimentary bedding, sub-meter scale differences in composition and color, and illuvial accumulation of clay minerals into subsurface horizons, all of which resulted from precipitation-driven pedogenic weathering of andesitic to rhyodacitic volcanic ash and tuff. Results from this work can help distinguish paleosols and weathering profiles from other types of sedimentary rocks in the geological record of Mars.

\section{Additional Information Acknowledgements} This work was performed on the ancestral homelands of the Numu, Cayuse, Umatilla, Walla Walla, and Confederated Tribes of the Warm Springs who were present before western settlement. Many thanks to Elizabeth Rampe and Paul Niles for the opportunity to work on this project and for providing research direction during a summer internship. Greg Retallack provided invaluable knowledge and guidance in support of this project. Barry Hughes and Megan Barrington assisted with fieldwork and entertained thoughtful discussion. Angela Olsen, Marshall Styczinski, Paul Regensberger and Joe Caggiano reviewed early versions of the manuscript. Funding from the Geological Society of America, The National Science Foundation, The Clay Minerals Society, The Society of Sedimentary Geology, and the Central Oregon Geoscience Society aided in the completion of this project.

\section{Author Contribution Statement}

A.P.B designed the study, performed laboratory analyses and drafted the manuscript. B.H.H identified similarities between Mars and John Day paleosols, assisted with fieldwork and provided VNIR spectra of paleosols. J.V.C guided all thermal analyses and facilitated data interpretation. B.S, J.V.C and D.W.M contributed to data analysis and interpretation. V.T. performed x-ray diffraction and assisted with interpretation of mineralogy. L.C.R.S aided with comparisons of modern soils with paleosols and supervised the project. All authors contributed to the manuscript.

\section{Author Disclosure Statement}




\section{This paper is a non-peer reviewed preprint submitted to EarthArXiv}

No competing financial interests exist.

\section{Supplementary data is available online at:}

1. Bishop, J. . et al. Phyllosilicate Diversity and Past Aqueous Activity Revealed at Mawrth Vallis, Mars. Science 830-834 (2008).

2. Bishop, J. L. et al. What the ancient phyllosilicates at Mawrth Vallis can tell us about possible habitability on early Mars. Planet. Space Sci. 86, 130-149 (2013).

3. Scheller, E. L., Ehlmann, B. L., Hu, R., Adams, D. J. \& Yung, Y. L. Long-term drying of Mars by sequestration of ocean-scale volumes of water in the crust. Science (80-. ). 372, 56-62 (2021).

4. Ye, B. \& Michalski, J. R. Precipitation-Driven Pedogenic Weathering of Volcaniclastics on Early Mars. Geophys. Res. Lett. 48, 1-10 (2021).

5. Murchie, S. et al. Compact Reconnaissance Imaging Spectrometer for Mars ( CRISM ) on Mars Reconnaissance Orbiter ( MRO ). J. Geophys. Res. 112, 1-57 (2007).

6. Carter, J., Loizeau, D., Mangold, N., Poulet, F. \& Bibring, J. Widespread surface weathering on early Mars : A case for a warmer and wetter climate. Icarus 248, 373-382 (2015).

7. Loizeau, D. et al. Quantifying widespread aqueous surface weathering on Mars: The plateaus south of Coprates Chasma. Icarus 302, 451-469 (2018).

8. Franklin, R. et al. Oxia Planum : The Landing Site for the ExoMars. Astrobiology 21, 1-22 (2021).

9. Bristow, T. F. et al. Clay mineral diversity and abundance in sedimentary rocks of Gale crater, Mars. Sci. Adv. 4, 1-9 (2018).

10. Ehlmann, B. L., Mustard, J. F. \& Murchie, S. L. Geologic setting of serpentine deposits on Mars. Geophys. Res. Lett. 37, 1-5 (2010).

11. Ehlmann, B. L. et al. Clay minerals in delta deposits and organic preservation potential on Mars. Nature 1, 355-358 (2008).

12. Michalski, J. R. et al. Constraints on the crystal-chemistry of Fe / Mg-rich smectitic clays on Mars and links to global alteration trends. Earth Planet. Sci. Lett. 427, 215-225 (2015).

13. Vaniman, D. T. et al. Mineralogy of a Mudstone at Yellowknife Bay, Gale Crater, Mars Mineralogical Analysis and Quantitative Mineralogy. Science (80-. ). 1-14 (2014) doi:10.1126/science.1243480.

14. Bishop, J. L. et al. Surface clay formation during short-term warmer and wetter conditions on a largely cold ancient Mars. Nat. Astron. 2, 206-213 (2018).

15. Horgan, B., Bishop, L., Christensen, P. R. \& Bell, J. F. Potential ancient soils preserved at Mawrth Vallis from comparisons with Eastern Oregon paleosols: Implications for Early Martian Climate. Third Conf. Early Mars 7074, 12-13 (2012).

16. Cannon, K. M., Stephen, W. \& Mustard, J. . Primordial clays on Mars formed beneath a steam or supercritical atmosphere. Nature 552, 88-91 (2017).

17. Ehlmann, B. L. et al. Subsurface water and clay mineral formation during the early history of Mars. Nature 479, 53-60 (2011).

18. Retallack, G. J. Soil of the Past. (Wiley Blackwell, 2019).

19. Smith, R. \& \& Horgan, B. H. N. Nanoscale Variations in Natural Amorphous and Nanocrystalline 


\section{This paper is a non-peer reviewed preprint submitted to EarthArXiv}

Weathering Products in Mafic to Intermediate Volcanic Terrains on Earth : Implications for Amorphous Detections on Mars. J. Geophys. Res. Planets 126, 1-30 (2021).

20. Horgan, B. Strategies for Searching for Biosignatures in Ancient Martian Sub-Aerial Surface Environments. Biosignature Preserv. Detect. Mars Analog Environ. 7463 (2016) doi:10.1089/ast.2016.1627.

21. Rye, R. \& Holland, H. Life associated with a 2 . 76 Ga ephemeral pond ?: Evidence from Mount Roe \# 2 paleosol. Geology 28, 483-486 (2000).

22. Heard, A. W. et al. Anoxic continental surface weathering recorded by the 2.95 Ga Denny Dalton Paleosol (Pongola Supergroup, South Africa). Geochim. Cosmochim. Acta 295, 1-23 (2021).

23. Heard, A. W. \& Kite, E. S. A probabilistic case for a large missing carbon sink on Mars after 3.5 billion years ago. Earth Planet. Sci. Lett. 531, 116001 (2020).

24. Liu, J. et al. Anoxic chemical weathering under a reducing greenhouse on early Mars. Nat. as (2021) doi:https://doi.org/10.1038/s41550-021-01303-5.

25. Retallack, G. J. Paleosols and paleoenvironments of early Mars. Geology 42, 755-758 (2014).

26. Hays, L. E. et al. Biosignature Preservation and Detection in Mars Analog Environments. Astrobiology 17, 363-400 (2017).

27. Lantz, C. et al. Planetary Terrestrial Analogues Library project: 1. characterization of samples by near-infrared point spectrometer. Planet. Space Sci. 189, 104989 (2020).

28. Bestland, E. . Alluvial Terraces and Paleosols As Indicators Of Early Oligocene Climate Change (John-Day Formation, Oregon). J. Sediment. Res. 67, 840-855 (1997).

29. Retallack, G. J., Bestland, E. . \& Fremd, T. . Eocene and Oligocene Paleosols of Central Oregon. Geol. Soc. Am. Spec. Pap. 344, 1-192 (2000).

30. Smith, R. ., Horgan, B., Rampe, E. \& Dehouck, E. The Composition of Amorphous Phases in Soils and Sediments on Earth and Mars. 49th Lunar Planet. Sci. Conf. 2018 14-15 (2018).

31. Sheldon, N. D., Retallack, G. J. \& Tanaka, S. Geochemical Climofunctions from North American Soils and Application to Paleosols across the Eocene - Oligocene Boundary in Oregon Geochemical Climofunctions from North American Soils and Application to Paleosols across the Eocene-Oligocene Boundary in Or. J. Geol. 110, 687-696 (2015).

32. Staff, S. S. Keys to Soil Taxonomy. United States Dep. Agric. 12, (2014).

33. Bestland, E. A. Fossil Andisols identified with mass-balance geochemistry (Oligocene John Day Formation, Oregon, U.S.A.). J. Sediment. Res. 72, 673-686 (2002).

34. Milliken, R. ., Mustard, J. ., Ehlmann, B. L., Bishop, J. L. \& Murchie, S. L. Interpreting and constraining the compositional and depositional environments of phyllosilicates on Mars. $G r$. Truth From Mars 4036, 7-8 (2008).

35. Bishop, J. L. et al. Multiple mineral horizons in layered outcrops at Mawrth Vallis, Mars, signify changing geochemical environments on early Mars. Icarus 341, 113634 (2020).

36. Deit, L. Le et al. Extensive surface pedogenic alteration of the Martian Noachian crust suggested by plateau phyllosilicates around Valles Marineris. J. Geophys. Res. 117, 1-25 (2012).

37. Dobrea, E. Z. N. et al. Mineralogy and stratigraphy of phyllosilicate - bearing and dark mantling units in the greater Mawrth Vallis / west Arabia Terra area : Constraints on geological origin. $J$. Geophys. Res. 115, 1-27 (2010).

38. Lowe, D. R. et al. Deposition of $>3.7$ Ga clay-rich strata of the Mawrth Vallis Group, Mars, in lacustrine, alluvial, and aeolian environments. GSA Bull. 17-30 (2020). 


\section{This paper is a non-peer reviewed preprint submitted to EarthArXiv}

1014 39. Loizeau, D. et al. History of the clay-rich unit at Mawrth Vallis, Mars: High- resolution mapping

1015

1016

1017

1018

1019

1020

1021

1022

1023

1024

1025

1026

1027

1028

1029

1030

1031

1032

1033

1034

1035

1036

1037

1038

1039

1040

1041

1042

1043

1044

1045

1046

1047

1048

1049

1050

1051

1052

1053

1054

1055

1056

1057

of a candidate landing site. J. Geophys. Res. Planets 1820-1846 (2015)

doi:10.1002/2015JE004894.Received.

40. Bishop, J. . et al. Mineralogy of layered outcrops at Mawrth Vallis and implications for early aqueous geochemistry on Mars. 47th Lunar Planet. Sci. Conf. 2, 2-3 (2016).

41. Retallack, G. J. Palaeosols of the Siwalik Group as a 15 Myr record of South Asian palaeoclimate. Mem. - Geol. Soc. India 32, 36-51 (1995).

42. Horgan, B. H. N. CLIMATE CHANGE AND A SEQUENCE OF HABITABLE ANCIENT SURFACE ENVIRONMENTS PRESERVED IN PEDOGENICALLY ALTERED SEDIMENTS AT MAWRTH VALLIS, MARS. in Lunar and Planetary Science Conference 3059 (2013).

43. Broz, A. P. Organic Matter Preservation in Ancient Soils of Earth and Mars. Life 10, (2020).

44. Butt, C. R. M., Lintern, M. J. \& Anand, R. R. Evolution of regoliths and landscapes in deeply weathered terrain - implications for geochemical exploration. Ore Geol. Rev. 16, 167-183 (2000).

45. Zauyah, S., Schaefer, C. E. G. R. \& Simas, F. N. B. Saprolites. Interpretation of Micromorphological Features of Soils and Regoliths (Elsevier B.V., 2018). doi:10.1016/b978-0444-63522-8.00003-6.

46. Beukes, N. J., Dorland, H., Nedachi, M. \& Ohmoto, H. Tropical laterites, life on land and the history of atmospheric oxygen in the Paleoproterozoic. Geology 30, 491-494 (2002).

47. Rye, R., Geological, D. \& Sciences, P. Life associated with a 2 . 76 Ga ephemeral pond ?: Evidence from Mount Roe \# 2 paleosol. Geology 483-486 (2000).

48. Watanabe, Y., Martin, J. E. . \& Ohmoto, H. Geochemical evidence for terrestrial ecosystems 2.6 billion years ago. Nature 408, (2000).

49. Watanabe, Y., Stewart, B. W. \& Ohmoto, H. Organic- and carbonate-rich soil formation 2.6 billion years ago at Schagen, East Transvaal district, South Africa. Geochim. Cosmochim. Acta 68 , 2129-2151 (2004).

50. Horgan, B., Baker, L., Carter, J. \& Chadwick, O. Where is the climate signature in the mineral record of early Mars? Fourth Conf. Early Mars 2017 3077, 2014-2015 (2017).

51. Liu, J., Michalski, J. R. \& Zhou, M. Intense subaerial weathering of eolian sediments in Gale crater, Mars. Sci. Adv. 7, (2021).

52. Barrington, M. . et al. Mastcam-Z Analog Spectral Imager. 51st Lunar Planet. Sci. Conf. 1595, 51-52 (2020).

53. Horgan, B. et al. New constraints from CRISM and MASTCAM spectra on the mineralogy and origin of Mt. Sharp geologic units, Gale Crater, Mars. 48th Lunar Planet. Sci. Conf. 3021, 2-3 (2017).

54. Rampe, E. B. et al. Mineralogy and geochemistry of sedimentary rocks and eolian sediments in Gale crater, Mars: A review after six Earth years of exploration with Curiosity. Geochemistry 80, (2020).

55. Morris, R. V. et al. Silicic volcanism on Mars evidenced by tridymite in high-SiO2 sedimentary rock at Gale crater. Proc. Natl. Acad. Sci. U. S. A. 113, 7071-7076 (2016).

56. Mahaffy, P. R. et al. The sample analysis at mars investigation and instrument suite. Space Sci. Rev. 170, 401-478 (2012).

57. Goesmann, F. et al. The Mars Organic Molecule Analyzer (MOMA) Instrument: Characterization of Organic Material in Martian Sediments. Astrobiology 17, 655-685 (2017). 


\section{This paper is a non-peer reviewed preprint submitted to EarthArXiv}

1058

1059

1060

1061

1062

1063

1064

1065

1066

1067

1068

1069

1070

1071

1072

1073

1074

1075

1076

1077

1078

1079

1080

1081

1082

1083

1084

1085

1086

1087

1088

1089

1090

1091

1092

1093

1094

1095

1096

1097

1098

1099

1100

1101

58. Bishop, J. L., Lane, M. D., Dyar, M. D. \& Brown, A. J. Reflectance and emission spectroscopy study of four groups of phyllosilicates: smectites, kaolinite-serpentines, chlorites and micas. Clay Miner. 43, 35-54 (2008).

59. Jones, R. C., Babcock, C. J. \& Knowlton, W. B. Estimation of the Total Amorphous Content of Hawai'i Soils by the Rietveld Method. Soil Sci. Soc. Am. J. 1108, 1100-1108 (2000).

60. Chipera, S. J. \& Bish, D. L. Baseline studies of the clay minerals society source clays: Colloid and surface phenomena. Clays Clay Miner. 49, 446-452 (2001).

61. Breecker, D. O., Sharp, Z. D. \& McFadden, L. D. Seasonal bias in the formation and stable isotopic composition of pedogenic carbonate in modern soils from central New Mexico, USA. Bull. Geol. Soc. Am. 121, 630-640 (2009).

62. Retallack, G. J. et al. Late Pleistocene mammoth trackway from Fossil Lake, Oregon. Paleogeography, Paleoclimatology, Paleoecol. (2018) doi:10.1016/j.palaeo.2018.01.037.

63. Lukens, W. E., Nordt, L. C., Stinchcomb, G. E., Driese, S. G. \& Tubbs, J. D. Reconstructing pH of paleosols using geochemical proxies. J. Geol. 126, 427-449 (2018).

64. Chemtob, S. M., Nickerson, R. D., Morris, R. V., Agresti, D. G. \& Catalano, J. G. Synthesis and structural characterization of ferrous trioctahedral smectites: Implications for clay mineral genesis and detectability on Mars. J. Geophys. Res. E Planets 120, 1119-1140 (2015).

65. Yant, M. et al. Visible, near-infrared, and mid-infrared spectral characterization of Hawaiian fumarolic alteration near Kilauea' s December 1974 flow: Implications for spectral discrimination of alteration environments on Mars. Am. Mineral. 103, (2018).

66. Danielson, J. . et al. Characterization of outcrops containing 'doublet' spectra at Mawrth Vallis, Mars. Lunar Planet. Sci. Conf. 2019, 1-179 (2019).

67. Horgan, B., Christensen, P. \& Iii, J. F. B. Searching for pedogenic phyllosilicates in ancient martian soils. AGU Fall Meet. 1999 (2011).

68. Horgan, B. et al. The effects of climate, environment, and diagenesis on the spectral properties of volcanic soils. in GSA Annual Meeting, Cordilleran Section 1-24 (2017).

69. Novoselov, A. A., Roberto, C. \& Filho, D. S. Potassium metasomatism of Precambrian paleosols. Precambrian Res. 262, 67-83 (2015).

70. Earnest, C. M. Thermal analysis of selected illite and smectite clay minerals. Part II. Smectite clay minerals. in Thermal Analysis in the Geosciences (eds. Smykatz-Kloss, W. \& Warne, S. S. J.) 288-312 (Springer Berlin Heidelberg, 1991).

71. Mcadam, A. ., Sutter, B., Archer, P. ., Franz, H. . \& Eigenbrode, J. . The chemistry and mineralogy of the Glen Torridon clay-bearing unit from Mars Science Laboratory Sample Analysis at Mars. 51 st Lunar Planet. Sci. Conf. 2243, 60-74 (2020).

72. Smith, R. J., Rampe, E. B., Horgan, B. H. N. \& Dehouck, E. Deriving Amorphous Component Abundance and Composition of Rocks and Sediments on Earth and Mars. J. Geophys. Res. Planets 123, 2485-2505 (2018).

73. Sutter, B. et al. Evolved gas analyses of sedimentary rocks and eolian sediment in Gale Crater, Mars: Results of the Curiosity rover's sample analysis at Mars instrument from Yellowknife Bay to the Namib Dune. J. Geophys. Res. Planets 2574-2609 (2017) doi:10.1002/2016JE005225.

74. Sutter, B., Laurer, H. ., Golden, D. ., Ming, D. . \& Boynton, W. . PHOENIX LANDER'S THERMAL EVOLVED GAS ANALYZER: DIFFERENTIAL SCANNING CALORIMETER AND MASS SPECTROMETER DATABASE DEVELOPMENT. in 35th Lunar and Planetary Science Conference vol. 21 1-3 (2008). 


\section{This paper is a non-peer reviewed preprint submitted to EarthArXiv}

1102 75. Ming, D. W. et al. Volatile and Organic Compositions of Sedimentary Rocks in Yellowknife Bay,

1103

1104

1105

1106

1107

1108

1109

1110

1111

1112

1113

1114

1115

1116

1117

1118

1119

1120

1121

1122

1123

1124

1125

1126

1127

1128

1129

1130

1131

1132

1133

1134

1135

1136

1137

1138

1139

1140

1141

1142

1143

1144

1145

Gale Crater , Mars. Sci. Express 1-15 (2014) doi:10.1126/science.1245267.

76. Hogancamp, J. V et al. Identification of phyllosilicates in mudstone samples using water releases detected by the Sample Analysis at Mars (SAM) instrument in Gale Crater, Mars. Lunar Planet. Sci. XLVIII 1620 (2017) doi:10.1126/science.1243480.

77. Mcadam, A. et al. Constraints on Gale Crater mudstone from MSL SAM evolved water. in Lunar and Planetary Science XLVIII 7-8 (2017). doi:10.1126/science.1245267.

78. Mcadam, A. et al. Sulfur-bearing phases detected by evolved gas analysis of the Rocknest aeolian deposit, Gale Crater, Mars. J. Geophys. Res. Planets 119, 6121-6139 (2014).

79. François, P. et al. Magnesium sulfate as a key mineral for the detection of organic molecules on Mars using pyrolysis. J. Geophys. Res. - Planets 61-74 (2015) doi:10.1002/2015JE004884.Received.

80. Driese, S. G. \& Ober, E. G. Paleopedologic and paleohydrologic records of precipitation seasonality from early Pennsylvanian 'Underclay' paleosols, U.S.A. J. Sediment. Res. 75, 9971010 (2005).

81. Retallack, G. J. Untangling the effects of burial alteration and ancient soil formation. Annu. Rev. Earth Planet. Sci. 183-206 (1991).

82. PiPujol, M. D. \& Buurman, P. The distinction between ground-water gley and surface-water gley phenomena in Tertiary paleosols of the Ebro basin, NE Spain. Palaeogeogr. Palaeoclimatol. Palaeoecol. 110, 103-113 (1994).

83. Allen, J. R. L. Time scales of colour change in late Flandrian intertidal muddy sediments of the Severn Estuary. Proc. Geol. Assoc. 97, 23-28 (1986).

84. Spinola, D. N. et al. Diagenetic reddening of Early Eocene paleosols on King George Island, Antarctica. Geoderma 315, 149-159 (2018).

85. Sheldon, N. D. Pedogenesis and geochemical alteration of the Pacific Gorge subgroup Columbia River basalt, Oregon. Bull. Geol. Soc. Am. 115, 1377-1387 (2003).

86. Solleiro-Rebolledo, E. et al. Paleosols beneath a lava flow in the southern basin of Mexico: The effect of heat on the paleopedological record. Catena 137, 622-634 (2016).

87. Ming, D. W. \& Mumpton, F. . Zeolites in Soils. in Minerals in Soil Environments vol. 18 873-911 (1989).

88. Hay, R. . Stratigraphy and zeolitic diagenesis of the John Day formation of Oregon. 42, 199-252 (1963).

89. Steefel, C. I. \& Van Cappellen, P. A new kinetic approach to modeling water-rock interaction: The role of nucleation, precursors, and Ostwald ripening. Geochim. Cosmochim. Acta 54, 2657-2677 (1990).

90. Chadwick, O. A. \& Chorover, J. The chemistry of pedogenic thresholds. Geoderma 100, 321-353 (2001).

91. Sclater, J. G. \& Christie, P. Continental Stretching: An explanation of the Post-Mid-Cretaceous subsidence of the Central North Sea Basin. J. Geophys. Res. 85, 3711-3739 (1980).

92. Bishop, J. L. \& Rampe, E. B. Evidence for a changing Martian climate from the mineralogy at Mawrth Vallis. Earth Planet. Sci. Lett. 448, 42-48 (2016).

93. Liivamägi, S. et al. Paleosols on the Ediacaran basalts of the East European Craton: a unique record of paleoweathering with minimum diagenetic overprint. Precambrian Res. (2018) doi:10.1016/j.precamres.2018.07.020. 


\section{This paper is a non-peer reviewed preprint submitted to EarthArXiv}

1146 94. Tosca, N. J. \& Knoll, A. H. Juvenile chemical sediments and the long term persistence of water at the surface of Mars. Earth Planet. Sci. Lett. 286, 379-386 (2009).

95. Berger, J. A. et al. Zinc and germanium in the sedimentary rocks of Gale Crater on Mars indicate hydrothermal enrichment followed by diagenetic fractionation. J. Geophys. Res. Planets 17471772 (2017) doi:10.1002/2017JE005290.

96. Wattel-Koekkoek, E., Buurman, P., Van der Plicht, J., Wattel, E. \& van Breeman, N. Mean residence time of soil organic matter associated with kaolinite and smectite. Eur. J. Soil Sci. 54, 269-278 (2003).

97. Li, Y., Cai, J., Song, M., Ji, J. \& Bao, Y. Influence of organic matter on smectite illitization : A comparison between red and dark mudstones from the Dongying Depression, China. Am. Mineral. 101, 134-145 (2016).

98. Elliott, W. C. \& Matisoff, G. Evaluation of kinetic models for the smectite to illite transformation. Clays Clay Miner. 44, 77-87 (1996).

99. Fang, Q. et al. Applied Clay Science New insights into microbial smectite illitization in the

100. Becker-Kerber, B. et al. The role of volcanic-derived clays in the preservation of Ediacaran biota from the Itajaí Basin (ca. 563 Ma, Brazil). Sci. Rep. 11, 1-10 (2021).

101. Kaiser, K. \& Guggenberger, G. The role of DOM sorption to mineral surfaces in the preservation of organic matter in soils. Org. Geochem. 31, 711-725 (2000). 